\title{
Prospective study of infectious and noninfectious diseases in oysters and fishes in three Gulf of Mexico estuaries
}

\author{
John A. Couch \\ Environmental Research Laboratory, US Environmental Protection Agency, Sabine Island, Gulf Breeze, Florida 32561, USA
}

\begin{abstract}
This study of 3 northem US Gulf Coast estuaries (Pensacola and Escambia Bays in Northwest Florida; Mobile Bay, Alabama; Pascagoula Harbor, Mississippi Sound, Mississippi) investigates: (1) frequencies of known or new diseases, including neoplasms, in oysters and fishes at sites among the estuaries; (2) general relations between disease frequency and human activity in influencing disease prevalences in fish and shellfish populations in coastal regions characterized by varying degrees of human impact. One offshore control station was collected quarterly (1979-1980) for fishdisease prevalence in comparison with the estuarine stations. Monthly samples of fishes and oysters were collected for disease analyses and diagnoses from August 1978 through August 1980. Sampling stations near heavily industrialized sites in Pascagoula Harbor yielded a higher frequency of diseased fishes and oysters compared to sampling stations in the other estuaries. Even though there were significant differences among disease prevalences in the 3 estuaries, the total prevalence of diseases in fishes and oysters suggested no grossly evident epizootics of pollutant-related disease at the time of study. However, further in-depth study of certain oyster and fish disorders encountered is recommended. Though far from pristine, the estuaries studied were not severely unhealthy environments as evidenced by scattered and relatively low disease prevalences. However, because the Gulf Coastal Plain will probably be the fastest growing region in the USA in the next decade, this study assists in providing base-line data for studies that should be made periodically on the health status of coastal biota in relation to the expected increase in human impact.
\end{abstract}

\section{INTRODUCTION}

Certain diseases of fishes and shellfishes from coastal populations have been suggested to be related to, caused by, or enhanced by pollutant activity (Couch \& Nimmo 1974, Mearns \& Sherwood 1974, 1977, Overstreet \& Howse 1977, Sindermann 1979). Considerable data were published from which inferences have been made that fishes and shellfishes inhabiting contaminated waters are at higher disease risks than those in cleaner environments. Most of these studies from which data derived were retrospective epizootiological efforts initiated after the fact, because certain fish diseases were increasingly observed or because fish kills were noted or had recurred frequently in specific bodies of water (Cooper \& Keller 1969, Perkins et al. 1972, Couch \& Nimmo 1974, Mearns \& Sherwood 1977, Stich et al. 1977, Hard et al. 1979, Kimura et al. 1984). Because of the retrospective nature of these studies the conclusions drawn from them were mainly confirma- tory of conditions known or suspected, or the basis for rejection of previously held hypotheses. Occasionally they have resulted in discovery of new, unsuspected hazards or risks (Kimura et al. 1984) to fish or shellfish populations.

Prospective studies of estuaries, without prior knowledge of disease prevalence, to determine previously undetected frequencies and relations of diseases in fishes and shellfishes have been rare (McCain et al. 1979). Therefore, a need existed to determine prospectively if populations of fishes and shellfishes at higher disease risks in variably impacted areas could be identified as possible a priori indicators of contamination with standard sampling and pathological methods.

The present, prospective study of 3 northern Gulf Coast estuaries (Pensacola and Escambia Bays in Northwest Florida; Mobile Bay, Alabama; Pascagoula Harbor in Mississippi Sound, Mississippi) was begun in August 1978. The specific goal was to determine monthly and annual frequencies of known or new 
chronic diseases, including neoplasms, in oysters and fishes for $2 \mathrm{yr}$ at selected sites among the 3 estuaries.

\section{STUDY SCOPE, SITES, MATERIALS, METHODS}

Sampling methods. Oysters (Crassostrea virginica) were collected at 1 or more stations within each estuary (Fig. 1a, b, c) once each mo for 24 mo. Numbers taken per mo were determined by availability. A minimum of 30 oysters per selected station per mo was obtained; at certain times and stations up to 200 oysters $\mathrm{mo}^{-1}$ were taken. Oysters were placed in damp cloth sacks and returned to the laboratory for opening and gross examination. Oyster tongs were used in water deeper than $1 \mathrm{~m}$. Hand collection of oysters was possible at some shallow stations.

Fishes were collected by otter trawl (4 to $6.7 \mathrm{~m}$ ). Trawls lasted at least $30 \mathrm{~min}$ and were done once per mo for 25 mo at each of the designated stations in each estuary (Fig. 1). No specific number of fishes was set $a$
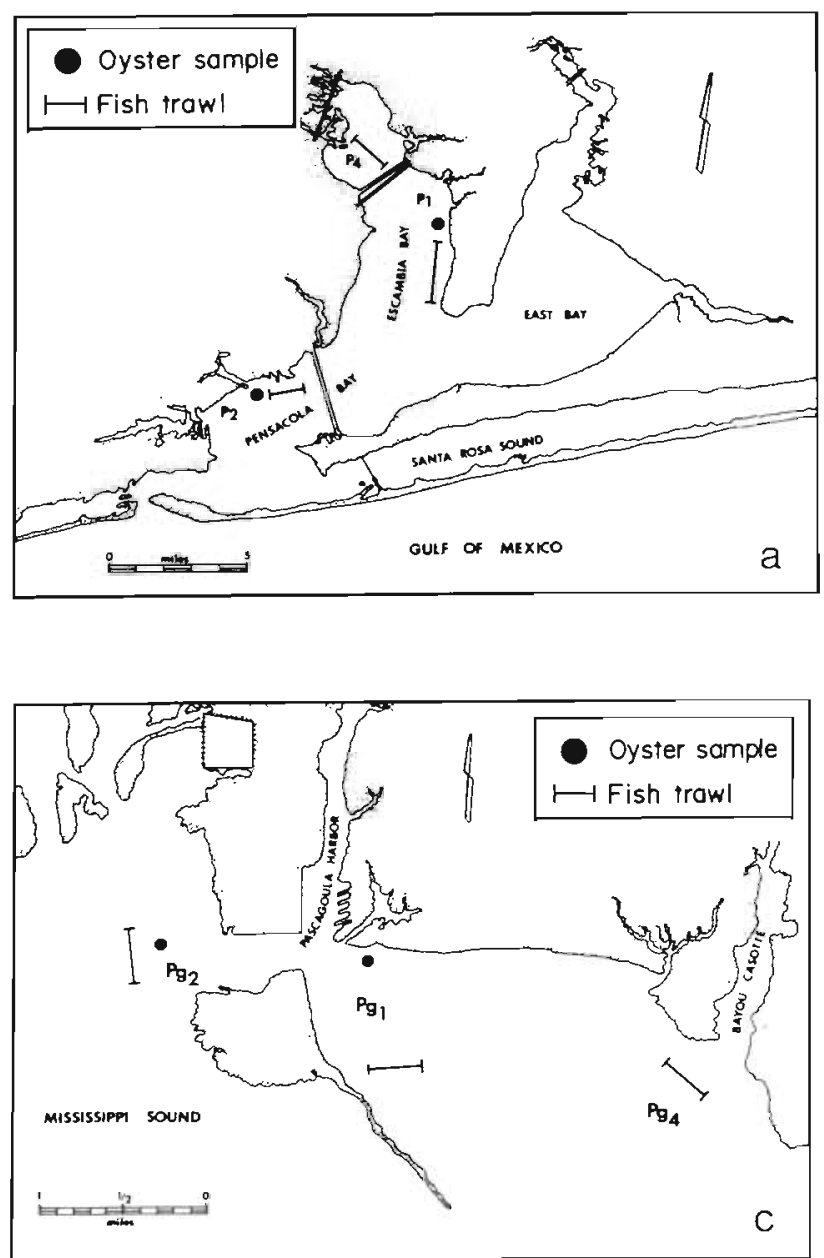

priori for examination. Fishes caught in the trawl were examined in the boat, as time permitted, by external and internal necropsy. In all, 11,987 fishes were necropsied.

An offshore station (Fig. 1d) was attended once per quarterly period during 1979-1980 (4 samples in all); because the offshore station was in water too deep for trawling, fish samples were taken by hook and line. No diseased fishes were collected at the offshore station, although gross external and internal examination was made of each fish caught.

At all stations, at times of sampling, observations were recorded on water temperatures and turbidity, bottom and top salinities, and weather conditions.

Description of estuarine sampling stations: Pensacola/Escambia Bay estuarine system (Fig. 1a). Station P1 was located at the State of Florida oyster reseeding project just offshore at Trout Bayou. Oysters were tonged directly from the shell pile in a depth of 2 to $3 \mathrm{~m}$. Fish were collected by trawling between the shell pile and the shoreline on a mud and remnant
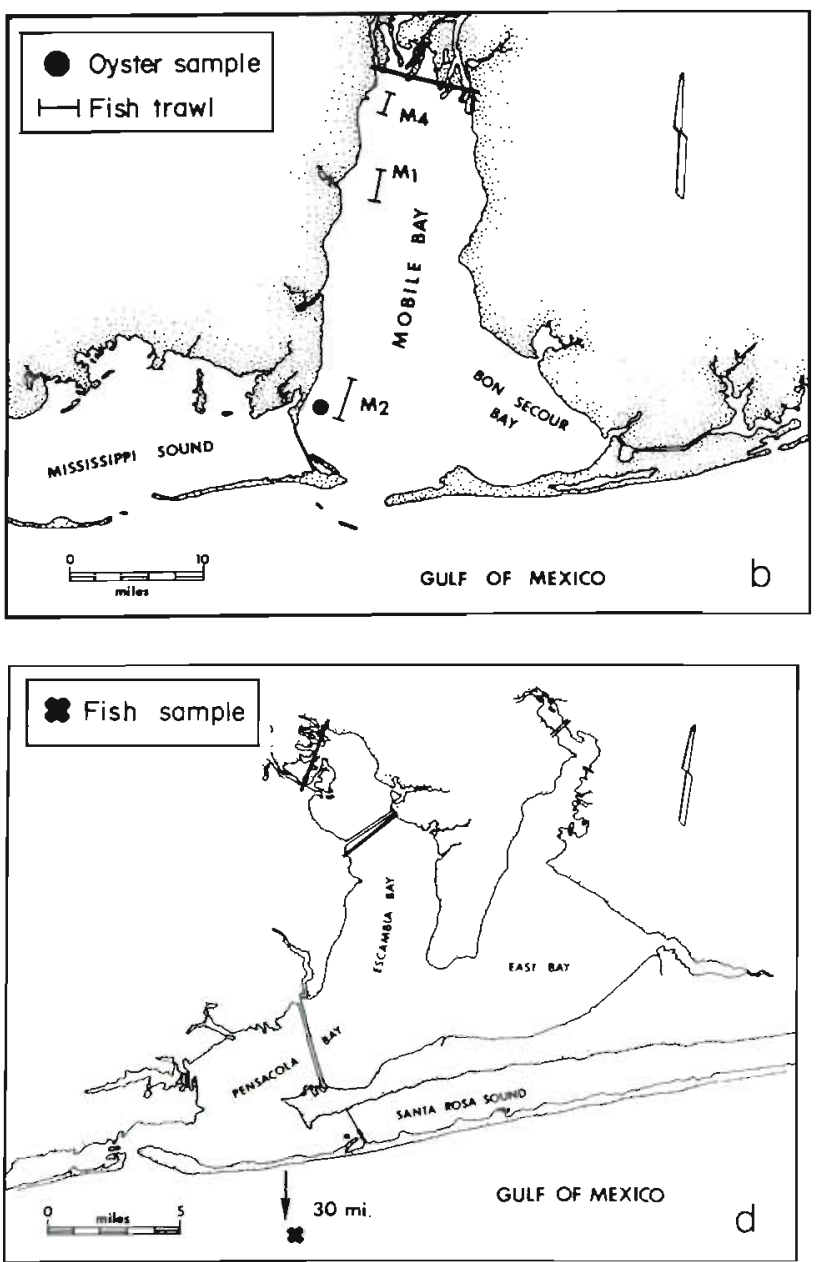

Fig. 1. Charts of study areas showing sampling sites. (a) Pensacola Bay system (3 sites); (b) Mobile Bay system (3 sites); (c) Pascagoula Harbor portion of Mississippi Sound (3 sites); (d) offshore comparison site with approximate sampling site 
oyster shell botton. Salinity here ranged from 2 to $24 \mathrm{ppt}$ on the bottom. Surface water temperature varied from a low of $10.0^{\circ} \mathrm{C}$ in March 1980 to a high of $30.0^{\circ} \mathrm{C}$ in August 1979. During the 25 mo sampling period examination was made of 1812 fishes including 20 families and 32 species. Trawl catches were composed predominantly of sciaenids: spot Leiostomus xanthurus (35\%), Atlantic croakers Micropogan undulatus $(44 \%)$ and white seatrout Cynoscion arenarius $(15 \%)$.

Station $P 2$ was located at the mouth of Bayou Chico in Pensacola Bay. Oysters were abundant on the rubble piles along the western edge of the approach channel. They were collected by wading and chipping them from rocks. Oyster samples also were taken from this station at a depth of $2 \mathrm{~m}$ between the rubble and the sandbar bordering the western edge of the channel, using tongs. Fish trawls were taken east of the channel in 2 to $25 \mathrm{~m}$ of water over a sand-mud bottom. Necropsy examination of 1622 of these fishes was performed in the field. Sciaenids composed $76 \%$ of the catch. In addition, the carangid Chloroscombrus chrysurus accounted for $9 \%$ of all trawl hauls. Ten fishes possessed overt lesions and were saved for histological analyses. Low and high salinity readings for P2 were 2 and $24 \mathrm{ppt}$, respectively, on both surface and bottom. Surface water temperature varied from 7.0 to $30.0^{\circ} \mathrm{C}$.

Station P4 was a large area extending from the north side of the railroad trestle to the mouth of the Escambia River. Oysters could not be found at P4. Trawling was done in the vicinity of the railroad trestie in 2 to $3 \mathrm{~m}$ of water over a mud bottom. Spot, Atlantic croaker, silver and white seatrout (Cynoscion spp.), Gulf menhaden (Brevoortia patronus), and Atlantic threadfin herring (Opisthonema oglinum) comprised $92 \%$ of trawl and gill net catches; 749 fishes were necropsied from this station.

Mobile Bay was the largest estuarine system sampled in this study (Fig. 1b). Station M1 included that area within a 1 mile $(1.6 \mathrm{~km})$ radius of Hollinger channel on the western edge of the bay, and was used only for trawling and gill netting of fishes. Depth here was 2 to $3 \mathrm{~m}$; the bottom was composed of mud with substantial quantities of old oyster shell. A wide annual salinity variation (0 to $24 \mathrm{ppt}$ ) occurred here. Surface water temperature ranged between 7.5 and $32.0^{\circ} \mathrm{C}$. Atlantic croaker, spot, white seatrout and spotted seatrout composed $63 \%$ of trawl hauls from this station. Another $20 \%$ was contributed by clupeids, mostly Brevoortia patronus and Opisthonema oglinum. Species variation was moderately high with 37 species representing 18 families; 1592 of these were examined internally.

Station $M 2$ was located just northeast of the Dauphin Island bridge. Oysters were tonged from shell bottom in 1 to $3 \mathrm{~m}$ of water. Trawls were taken off the north- eastern edge of the oyster reef over a predominantly mud and old shell bottom at depths of 2 to $3 \mathrm{~m}$. Salinity range was 0 to $30 \mathrm{ppt}$ and surface water temperature varied from 7.5 to $33.0^{\circ} \mathrm{C}$. Atlantic croaker, spot and white seatrout comprised $67 \%$ of trawl and gill net hauls. Species diversity, however, was high, with 60 species and 31 families represented. Internal examination was performed on 1772 fishes.

Station M4 was added in October 1978. M4 encompassed that area between Dog River and the Mobile Causeway; most trawling was done in the immediate vicinity of Mobile Harbor. Depth was between 2 and $3 \mathrm{~m}$ over a predominantly mud bottom with occasional sandy areas. Salinity ranged from 0 to $22 \mathrm{ppt}$, and surface water temperature from 8 to $33^{\circ} \mathrm{C}$. Spot and croaker represented $53 \%$ of the catch. Another $31 \%$ was contributed by clupeids, mostly Brevoortia patronus and Opisthonema oglinum. Species diversity was moderate with 37 species representing 18 families. Internal examination was performed on 1403 fishes.

Pascagoula Bay (Mississippi Sound) (Fig. 1c). Station Pg1 located at the eastern bank of the mouth of the Pascagoula River was within $100 \mathrm{~m}$ of Ingall's shipbuilding complex. It was not uncommon to find the water here completely covered by a diesel oil slick and the air constantly thick with the odor of hydrocarbons. The Pascagoula River receives water from the lower Escatawpa River, and numerous processing plants and several municipal sewage treatment plants. At $\mathrm{Pg} 1$ oysters were chipped from rubble along the shoreline. Fish trawls were taken in 2 to $3 \mathrm{~m}$ of water along the eastern edge of Pascagoula Channel. Fishes comprising 25 families and 50 species were captured and examined. The sciaenidae accounted for $70 \%$ of the catch with spot and Atlantic croaker almost equally represented at $32 \%$ and $33 \%$, respectively. Clupeids $(17 \%)$, carangids $(6 \%)$ and ariids (2\%) composed most of the remaining haul. Internal examination was done on 1047 fishes, mostly sciaenids.

Station Pg2 is located along the northwestern edge of the Ingall's shipyard turning basin. A large oyster bed located here produced abundant oyster samples until July 1980 at which time approximately $75 \%$ were found to be fresh boxes and $1 \%$ gapers. In August 1980 $>90 \%$ were boxes. A large diesel oil spill was observed during this month. Fish trawls originated in the turning basin and ended at the mouth of the West Pascagoula River. Gill net sets were made occasionally at the mouth of the river. $\mathrm{Pg} 2$ was a fairly diverse fish station (61 species representing 29 families). Sciaenids represented only $47 \%$ of the total catch, the lowest percentage of sciaenids of any station in this study. Again, spot (17\%) and Atlantic croaker (16\%) were equally common, and white seatrout accounted for another $10 \%$ of the catch. The ariids Arius felius and 
Bagre marina were more numerous here than at any other station in the study and accounted for $15 \%$ of the catch. The clupeids (25\%) were well represented with the Atlantic threadfin herring (11\%) and the Gulf menhaden $(8 \%)$ the most common. A total of 1196 were necropsied.

Station Pg4 was located at the mouth of Bayou Cassotte, west of the Bayou Cassotte approach channel. This bayou is a site of several major industrial facilities including an oil refinery. Fish trawls were made adjacent to the approach channel on a highly reduced spoil bank where water depth varied from 1 to $3 \mathrm{~m}$. Gill net sets were made on the adjacent mudflat in $2 \mathrm{~m}$ of water. Fishes caught represented 47 species from 25 families. Sciaenids $(54 \%)$, ariids $(11 \%)$, clupeids $(16 \%)$, carangids (4\%), trichiurids $(3 \%)$ and mugilids ( $3 \%$ ) accounted for most of these fishes, and 794 fishes were necropsied.

Field examination. All fishes brought aboard the collection vessel were examined for chronic, internal and external macroscopic lesions - ranging from parasitic infections to tumourous conditions. A complete necropsy was made, i.e. the abdominal cavity was opened and internal organs examined. Purposely omitted was the recording of acute conditions that fit the description of 'fin rot' disease. This condition was not recorded because of its great variability, ranging from red fins to complete loss of fins, and because it may be incidental in frequency and related to multiple etiologies, some of which may not be anthropogenic related. Only those fishes with overt, external (including mouth and branchial chambers) chronic lesions or internal lesions were returned to the laboratory, fixed or preserved for further examination and diagnoses. All oysters brought aboard were classified as boxes (empty shells: dead for some time), gapers (meat still in shell: recently dead or still alive) or live (shells tightly closed). Only live oysters (tightly closed shells) or fresh gapers (weak but still responsive) were returned to the laboratory as part of the monthly oyster samples.

Laboratory necropsy and histopathological methods. Fishes and oysters returned to the laboratory, the first as individual disease cases and the second as monthly samples for detailed histopathological examination, were examined grossly and photographed for characteristics of lesions or disease. Fishes, if judged worthy of histological processing for further diagnosis, and oysters, as monthly samples, were prepared and processed for microscopic study by methods detailed in Couch et al. (1974). A transverse section approximately $1 \mathrm{~cm}$ thick was taken from behind the labial palps of each oyster. The sections included planes through the hepatopancreas, gonad, gut, stomach, gills, mantle, and vesicular connective tissue. For histological processing, the fixative of choice was usually Davidson's fixative, an AFA, seawater fixative. Routine sections ( $7 \mu \mathrm{m}$ thick) for diagnosis were from paraffin blocks, and were usually stained with Harris' hematoxylin and eosin, unless special diagnostic stains were required, e.g. acid-fast stain for Mycobacterium sp. Fish sections were studied in detail at required microscopic magnification. Selected tissues for electron microscopy were fixed in $2.5 \%$, buffered glutaraldehyde and post-fixed in $1 \%$ osmium tetroxide when the nature of the lesion suggested ultrastructural examination. Serial sections of a minimum of 30 oysters $\mathrm{mo}^{-1}$ (oyster station) ${ }^{-1}$ were screened at $50 \times$ on microfilm viewers and higher required magnification with research compound microscopes for diagnoses and enumeration of pathological conditions.

\section{RESULTS}

\section{Disorders and biological agents in oysters}

\section{Disease types}

Disorders found in oysters were classified as either infectious or noninfectious based on histological examination of monthly samples collected from each designated sampling site. The final classification of disease conditions was made on the basis of: (1) type of lesions; and (2) presence or absence of causative agents associated with lesion. Diseases that are commonly found in oysters and which have previously been described in detail will not be figured or described in detail here, but references to full accounts of these pathoses will be given. Diseases or anomalies that are new, rarely reported, or uniquely relevant to the goals of this study will be described and figured in pertinent detail. Lesions or infections that occurred infrequently and demonstrated no seasonal prevalence trends are reported in total (2 yr samples) prevalence ${ }^{1}$. Strong monthly or seasonal differences or trends in prevalence of a lesion or disorder will be described in more detail for the estuaries in which they were found.

\section{Infectious disorders}

Perkinsus marinum. This organism was the most frequently diagnosed infectious disease agent in oysters. It may cause systemic, lethal infections. The dis-

\footnotetext{
${ }^{1}$ Prevalence of a condition is defined as the percentage of a sample of animals with a given disorder or infection

$\left(\frac{\text { Number with condition }}{\text { Number examined }} \times 100=\right.$ prevalence of condition $)$

Therefore, prevalence of a condition may be expressed, when qualified, as monthly, or cumulatively as seasonal, annual, or total (i.e. 2 yr or 24 mo samples)
} 
ease is called 'dermo disease' which refers to the original species name of the causative agent (Dermocystidium marinum: Mackin et al. 1950). The agent, a natural oyster pathogen, is thought to be a protozoan species related to the coccidian Protozoa, although originally it was placed in the fungi (Perkins 1976). Numerous studies on the morphology, systematics, pathology, and oyster-pathogen relations have been published (Mackin et al. 1950, Mackin 1951, Ray 1954, Perkins 1976). Previous authors have reported strong seasonality and sporadic epizootics of $P$. marinum in Gulf Coast oyster populations (Quick \& Mackin 1971).

Table 1 gives the total prevalence of Perkinsus marinum for the 3 estuaries. This pathogen occurred most frequently in Pascagoula Harbor oysters (4\% of 4486 oysters). Mobile Bay and Pensacola Bay oysters were found less frequently infected. This prevalence was determined by histological examination, not with supplemental laboratory culture techniques that would have revealed light or cryptic infections. Therefore, this is a very conservative estimate of prevalence. During the period sampled (August 1978 to September 1980), no epizootics of P. marinum disease or related oyster diseases were found. Infected oysters were found mainly in late summer, but this time (of patent infections) has long been known to be the season characteristically associated with higher prevalence of this disease in natural or introduced oyster populations along the Atlantic and Gulf Coasts.

Ciliate Protozoa. Thigmotrichous ciliate protozoans, common commensals of bivalve mollusks, are usually nonpathogenic in their oyster hosts. They are, however, conspicuous, usually constant, associates of oysters in both gill and hepatopancreatic tissues (tubule lumina), and in heavy concentrations they may occlude or block water tubules in the gills and digestive tubules. Oysters from Mobile Bay were slightly more
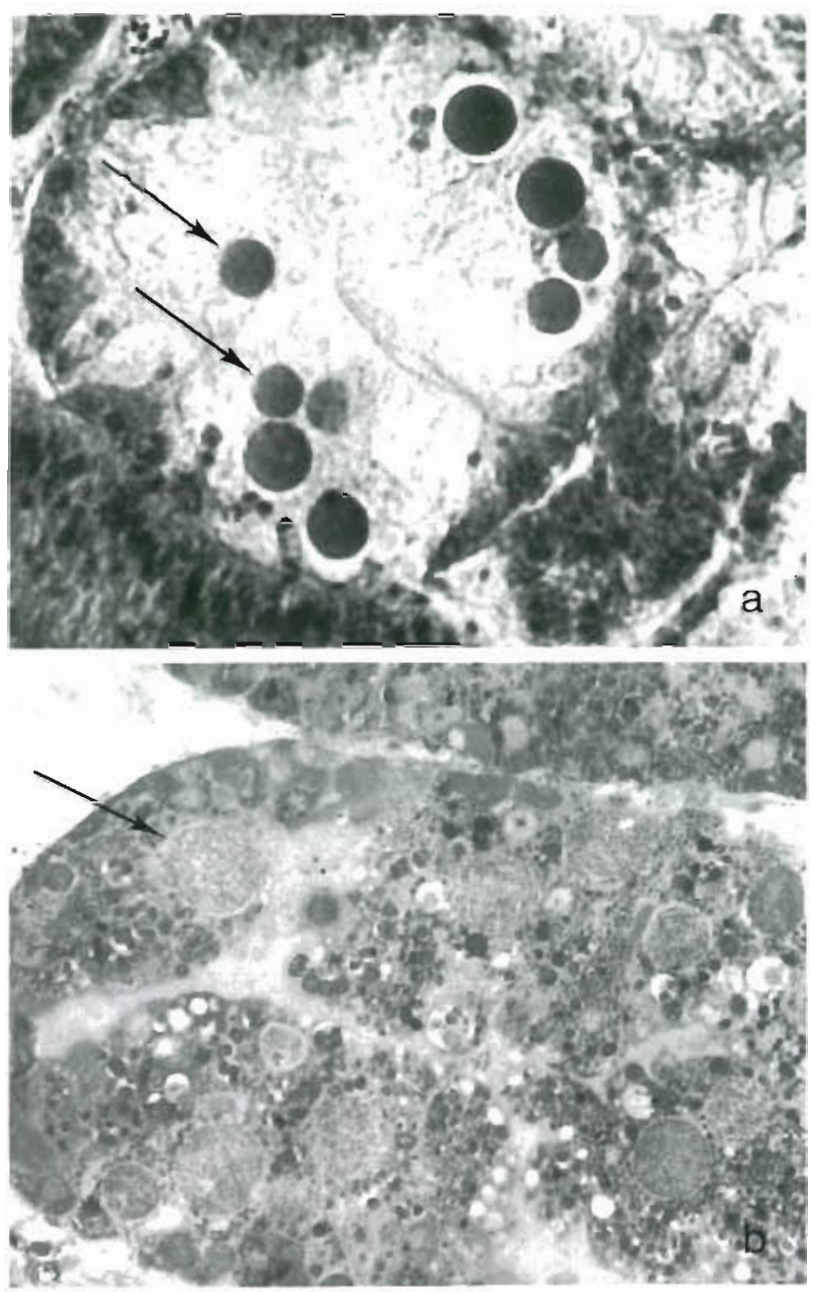

Fig. 2. Rickettsial inclusion bodies in epithelial cells of oyster digestive gland (arrows). Inclusions appear as basophilic spheres ( $\mathrm{H}$ and $\mathrm{E})(\times 630)$. (b) Rickettsial microcolonies (inclusion bodies) (arrow) in thick section of tissue embedded in plastic for electron microscopy $(\times 630)$

Table 1. Total oyster disease prevalences, Aug 1978 to Aug 1980 (derived from 24 monthly samples from each estuary)

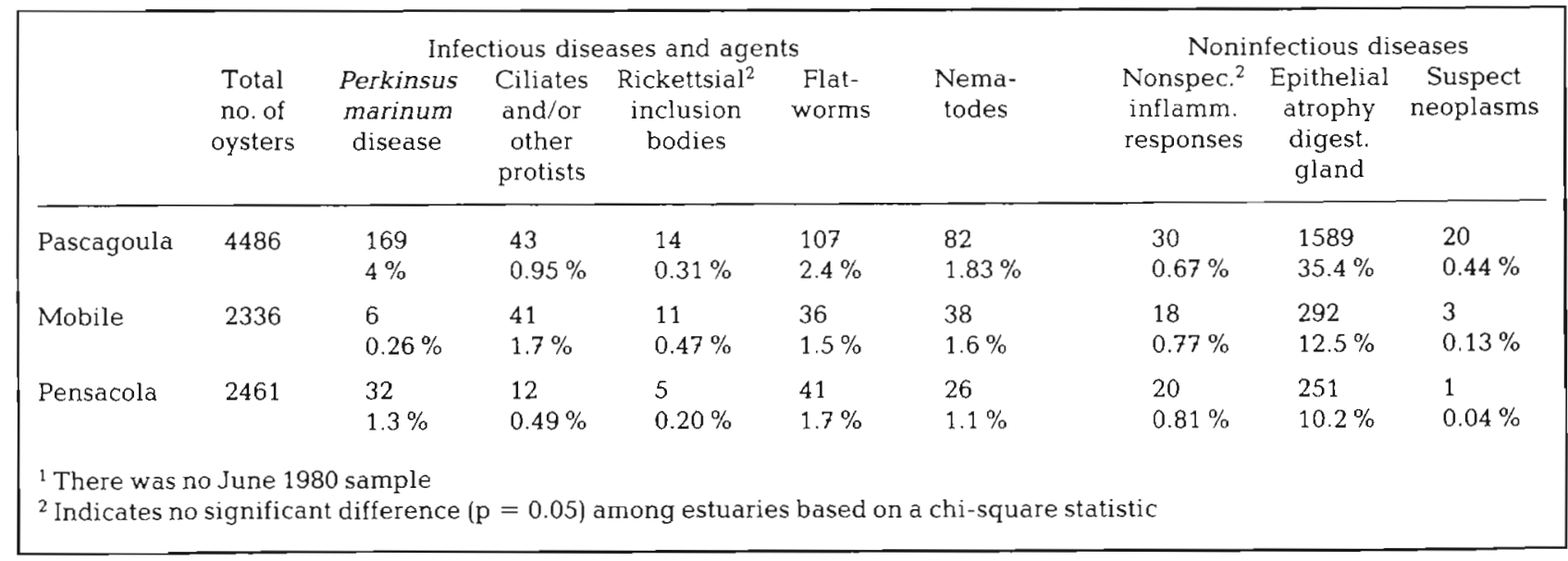




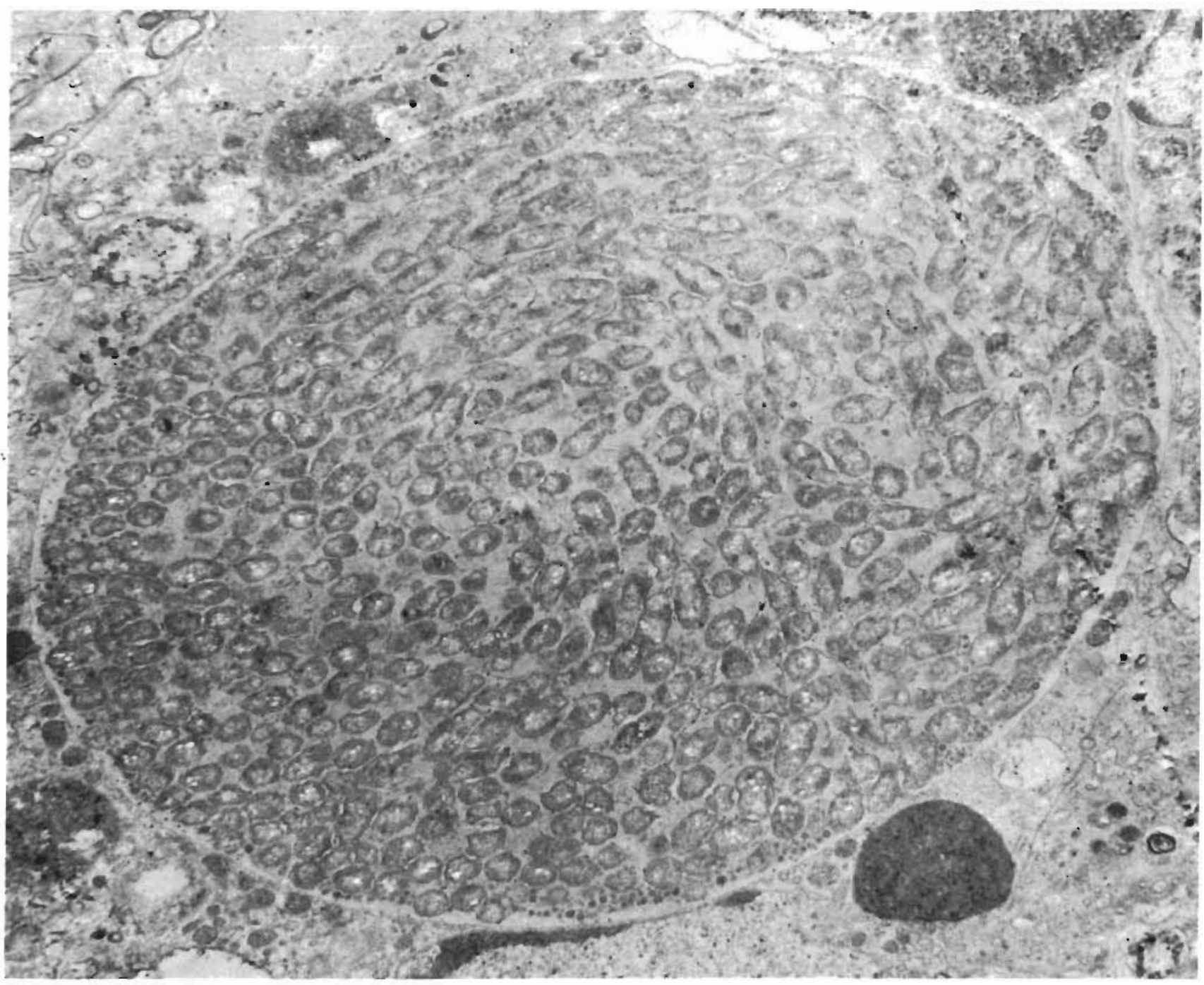

Fig. 3. Electron micrograph of rickettsial microcolony (inclusion body) in epithelial cell of digestive gland in oyster from northern Gulf Coast estuary. Note the single type of microorganism making up the intracytoplasmic colony enclosed within its own limiting membrane; note also the coccobacillary form of the rickettsia $(\times 13,600)$

significantly infested than oysters from the other estuaries (Table 1).

Rickettsia-like organism. A significant new finding during this study for the Gulf of Mexico was the discovery of a heretofore undescribed microorganism infecting epithelial cells of the digestive diverticula in oysters from all 3 estuaries. These intracellular organisms occur in microcolonies in epithelial cells of digestive diverticula (Fig. 2). Electron microscopy revealed that the inclusions consist of many microorganisms contained within membrane-limited microcolonies (Fig. 3). These microorganisms have the following features that strongly indicate they are rickettsia: (1) cell walls and underlying plasma membranes; (2) cytoplasm containing ribosomes and strands of DNA; (3) lack of elementary bodies characteristic of chlamy- dia; (4) correct size for rickettsia; and (5) are small, pleomorphic coccobacilli.

Pathologic effects of the organisms in oysters are: (1) physical distortion and disruption of host cell structure; (2) change in quantity and quality of cellular organelles, i.e. fewer mitochondria and compressed or absent nuclei; and (3) probable toxin production affecting host cell function. There is no evidence at present that the rickettsia-like agents are lethal to their oyster host, but occasional heavy infections have been found, suggesting the possibility of severe harm.

Because rickettsia and related microorganisms are known disease agents in humans and other mammals, their presence in oysters, which are eaten raw by man, poses a question of possible risks to public health. There is no evidence at present, however, that suggests 
human health is threatened by the species reported here. Similar organisms have been reported from clams (Mya sp.) by Harshbarger et al. (1977) in Chesapeake Bay, in clams by Buchanan (1978) from the coast of Scotland, and by Comps et al. $(1977,1978)$ in oysters and clams from France.

Less than $1 \%$ of oysters examined from each of the estuaries were infected with this organism (Table 1). There were no apparent monthly or seasonal trends in infection patterns and prevalence was not significantly higher for any given estuary.

Parasitic flatworms (helminths). Two species of flatworms, a cestode, Tylocephalum sp., and a digenetic trematode, Proctoeces sp., were found as sexually immature stages in oysters from each of the estuaries. The cestode Tylocephalum is found encysted in the vesicular connective tissues as a metacestode, and usually is not considered pathogenic to the oyster. Occasionally, however, host cellular response is elicited by dead or dying metacestodes, but cause little apparent effect on the condition of oysters.

Unencysted metacercariae of Proctoeces sp. were found in the gonadal follicles and ducts of oysters from each estuary (Fig. 4). The relation of this trematode to its oyster host is apparently not harmful. Considerable data on this subject are found in Winstead \& Couch (1981).

Total, combined prevalences of flatworms in oysters

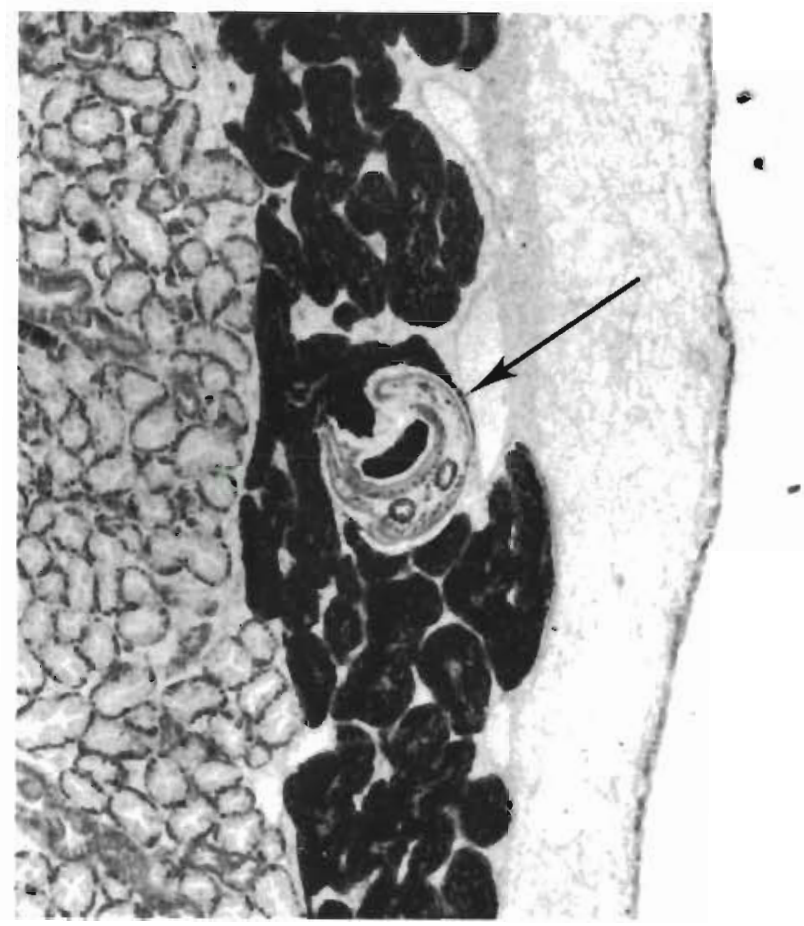

Fig. 4. Proctoeces sp. Trematode (flatworm) in gonadal duct of oyster (arrow). Note masses of sperm in gonad, surrounding the trematode $(\times 50)$ for the $2 y$ sampling period is presented for each estuary in Table 1. Oysters from Pascagoula Harbor had significantly higher prevalences of helminths than those from the other estuaries. No significant seasonal trends in prevalences were detected.

Parasitic roundworms (nematodes). A small but consistent number of oysters from each estuary was infested with juvenile stages of an unidentified nematode. Sections of these worms were found in vesicular, connective tissues of the oysters. In some cases, a cellular infiltrate was associated with the presence of the worm, but generally the worms appeared to cause little harm to the oysters. No significant seasonal or estuarine trends were found in the prevalences of the worms (Table 1).

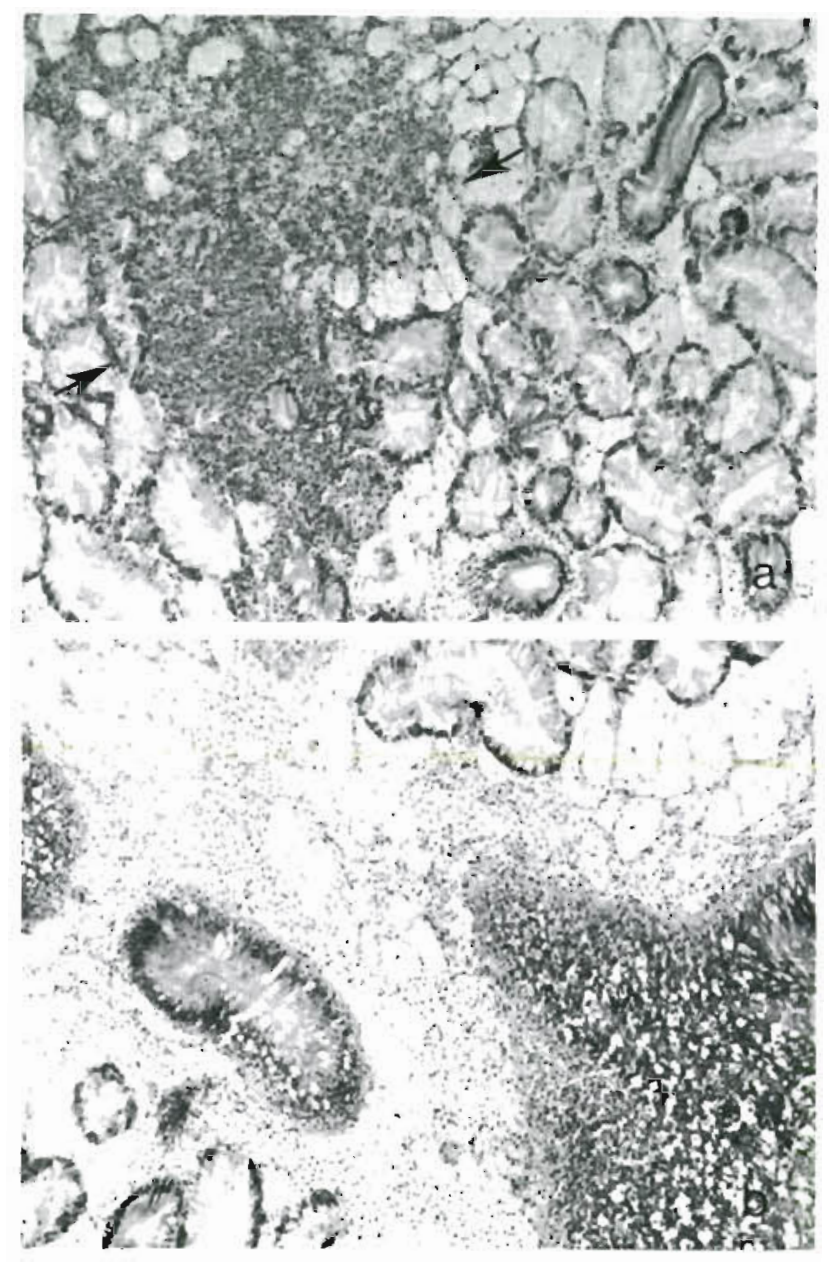

Fig. 5. (a) Focal accumulation of hemocytes in the digestive gland region of an oyster illustrating a nonspecific, focal inflammatory response (arrow), and the absence of observable etiologic agent ( $\times 80)$. (b) Diffuse, systemic hemocytic mobilization illustrating nonspecific inflammatory response widespread in the body of an oyster. Note the general distribution of hemocytes suggesting a diffuse hemocytosis $(\times 80)$ 
Noninfectious disease conditions

Noninfectious abnormalities found in oysters were of 3 major types: (1) nonspecific inflammatory responses; (2) digestive diverticula atrophy; (3) suspected hemocytic neoplasms or cellular proliferative disorders. For all of these conditions, no infectious etiology was identified, although the possibility that invasive microorganisms were causative in certain instances cannot be ruled out completely.
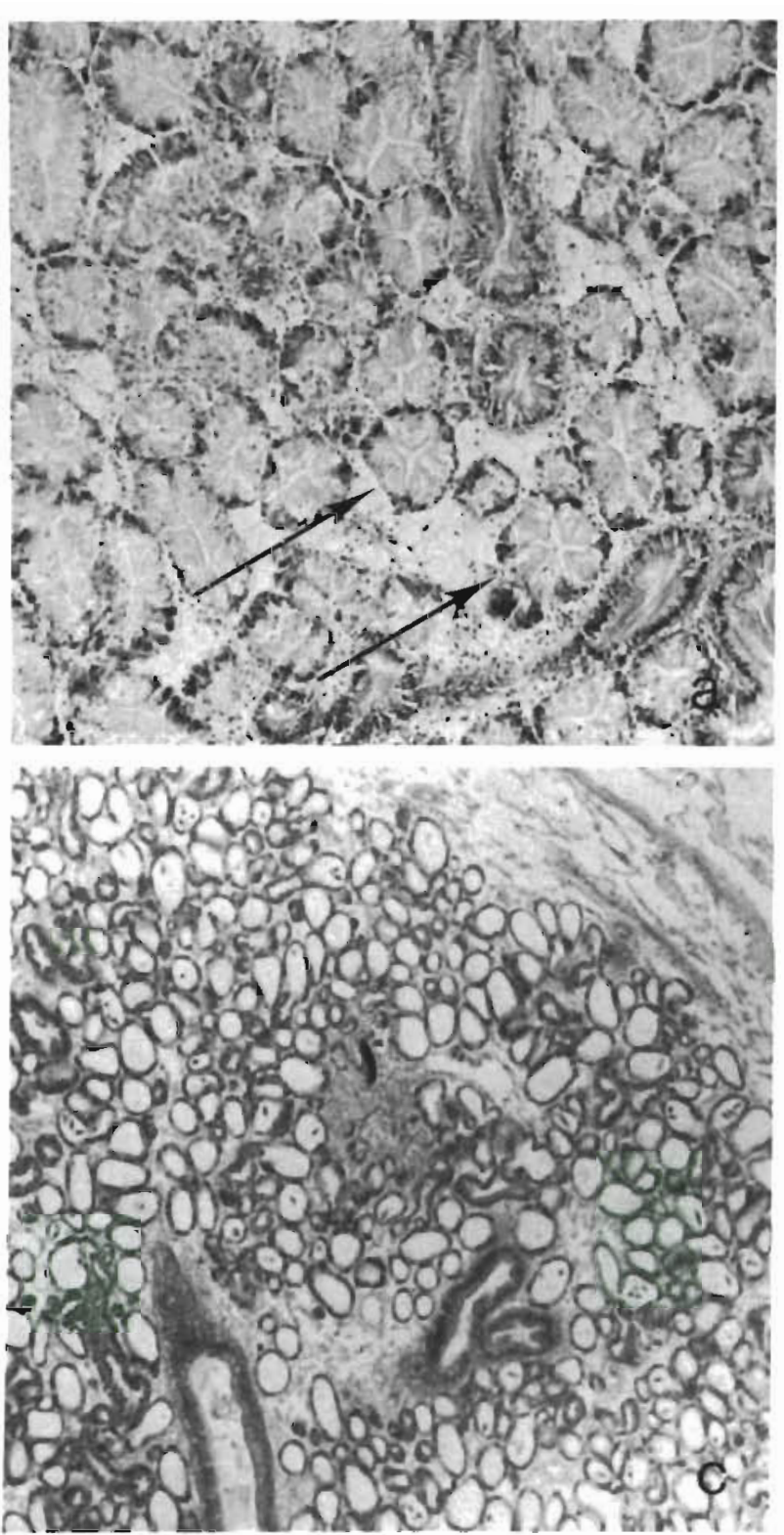

Nonspecific inflammatory responses. A relatively few oysters had infiltrates of hemocytes suggestive of an acute, systemic or focal cellular response to cellular or tissue damage (Table 1). Focal accumulations of hemocytes in the vesicular connective tissues (Fig. 5a) were termed nonspecific inflammatory responses when no causative agent could be directly associated with the cellular accumulations. In oysters with such lesions, there were usually other histopathologic indications of poor condition such as disorganized vesicu-

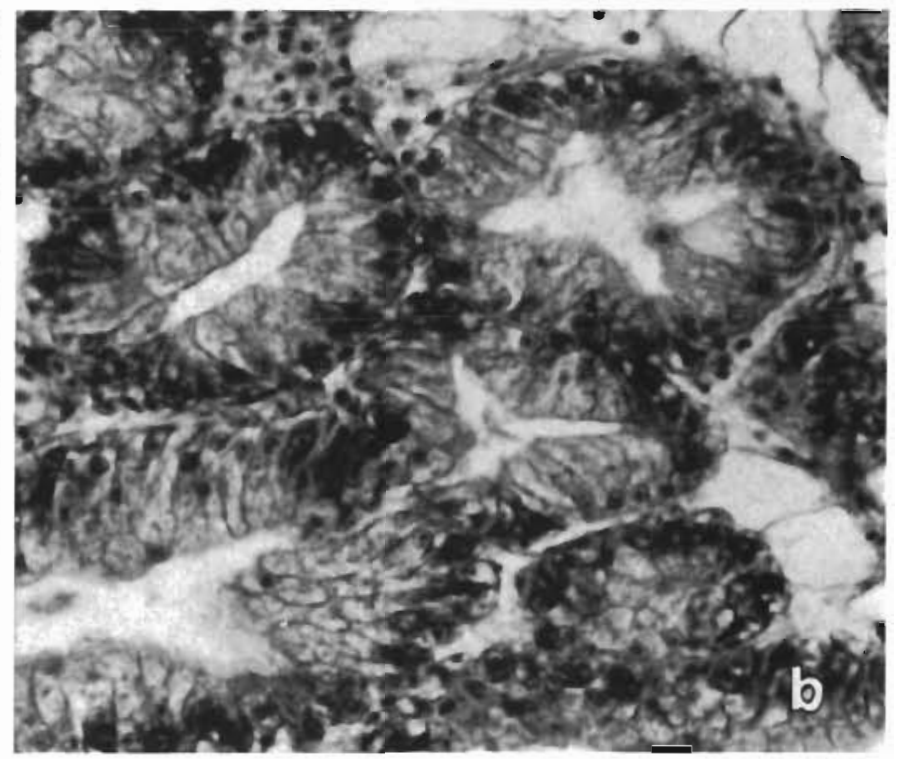

Fig. 6. (a) Normal digestive diverticula in nonstressed, normal oyster. Note thick, deep epithelium and the triradiate and quadriradiate lumina in the diverticula formed by the normal, thick epithelium (arrows). Compare with (c) for low magnification diagnosis $(\times 100)$. (b) Higher magnification of normal digestive diverticula. Again note the triradiate and quadriradiate lumina formed by the normal, thick epithelium $(\times 450)$. (c) Low magnification micrograph of abnormal digestive diverticula characterized by atrophic epithelia resulting in greatly enlarged, round lumina. Note the consistent, widespread nature of this atrophy throughout the gland. Compare directly with normal gland in (a) ( $\times 50)$. (d) Higher magnification of abnormal, atrophied digestive diverticular epithelium (arrow). Compare with (b) (normal) and (c) $(\times 450)$ 
lar connective tissue cells and necrosis of epithelia layers of gut or mantle. The focal inflammatory responses could be distinguished from diffuse, systemic, hemocytic mobilizations characterized by a general increase in hemocytes (hemocytosis) throughout the histologic sections of the oysters (Fig. 5b).

The occurrence of nonspecific inflammatory responses is probably indicative of stress, unrecognized injury, or the presence of submicroscopic agents in oysters. It has been noted that systemic hemocytosis in oysters is often associated with starvation and spawning-induced stress as well as chemically-induced stress (Couch, in Lowe et al. 1972, Couch et al. 1979). There were no noticeable seasonal or estuarine trends.

Digestive diverticulum atrophy. The digestive gland or hepatopancreas of oysters is similar to that of most bivalve mollusks in structure and function. The gland possesses ducts that arise in the wall of the stomach. These ducts are ciliated and give rise distally to diverticula (blind tubules) formed by a normally tall, columnar, nonciliated epithelium. In sections of normal, well-nourished oysters, the lumina of the diverticula appear tri- or quadriradiate because of the thick epithelium of the diverticulum (Fig. 6a, b).

The most prevalent and one of the more striking histopathologic findings in oysters during this study was an atrophic modification of the digestive diverticular epithelia in substantial numbers of oysters (Fig. 6c, d \& 7). This atrophy was characterized by a severe reduction in epithelial height when compared to normal diverticulum epithelial height. This caused the lumina of the diverticula to appear round and dilated, instead of the normal tri- or quadriradiate form in histologic sections (Fig. 6a, b \& 8). Occasionally,

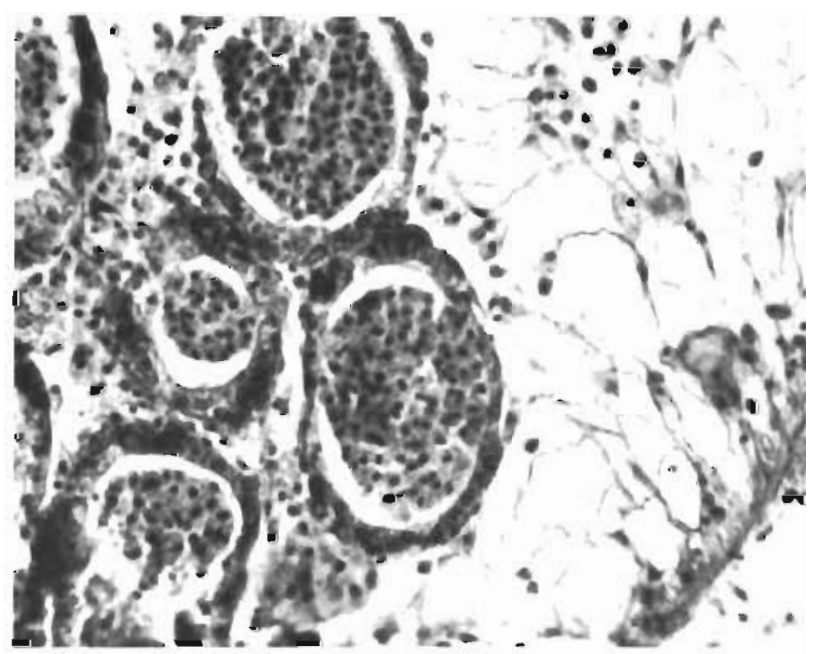

Fig. 7. Ultimate possible pathologic fate, associated with atrophic epithelium sloughing of cells, and necrosis. Note sloughed cells in lumina of diverticula that have atrophic epithelia $(\times 300)$ tubular degeneration and necrosis (Fig. 7) were associated with severe atrophy. This degeneration was characterized by sloughed necrotic material present in lumina of the atrophic tubules (Fig. $7 \& 8$ ) which might occur at any time during the atrophic process, but most often as a final event. Some oysters suffering from this condition also had systemic hemocytosis and vesicular connective tissue edema, indicating a state of physiological stress.

This condition occurred more frequently in oysters from all estuaries than did any other pathologic condition (Table 1). Its total prevalence (18 mo in 1979-1980) was highest in oysters from the Pascagoula Harbor portion of Mississippi Sound (Table 1). Total prevalence was significantly different among the estuaries (Chi-square test). Thirty-six \% of all oysters examined during 1 yr from Pascagoula displayed atrophic epithelia in their digestive diverticula; 10 to $12 \%$ of all oysters from the other estuaries had such conditions.

Seasonal trends in prevalence for the atrophic changes were found in oysters from each of the estuaries. Prevalences of this condition were found to peak biphasically at slightly different times of the year for each estuary (Fig. 9). However, in 2 estuaries the higher prevalence occurred generally in fall-winter (Oct to Jan) and late spring-early summer periods (Apr to Jun; Fig. 9). Prevalence of atrophy in Mobile Bay oysters departed from the other estuarine prevalences in the summer period in that it peaked in August (Fig. 9) as well as in January.

In each of 2 of the estuaries (Pascagoula and Pensacola), there were 2 oyster sampling stations, spatially removed from one another (Fig. 1a, c). Monthly prevalences of the diverticular atrophy for oysters from these stations are plotted in Fig. 9 and may be compared directly with one another for each of the estuaries. The frequency of atrophy was obviously seasonally higher for Station Pg2 than for Pg1 in the Pascagoula estuary, and alternately high for P1 and for P2 in Pensacola estuary (Fig. 9); seasonal prevalence peaks differed for each of the stations in the Pensacola estuary.

Possible etiologies of the diverticular atrophy are uncertain, but similar conditions have been experimentally induced in oysters and mussels by toxic chemicals (Couch, in Lowe et al. 1972, Moore et al. 1978, Moore \& Clarke 1982, Rasmussen 1982, Couch 1984). Geographical site variation in the frequency of this condition in monthly samples, and differences of total prevalence $36 \%$ of oysters from Pascagoula vs. 10 to $12 \%$ of oysters from Mobile and Pensacola) in different estuaries suggest localized environmental factors as possible controlling factors in its genesis or modulation. These possibilities will be distcussed in the final section of this report. 


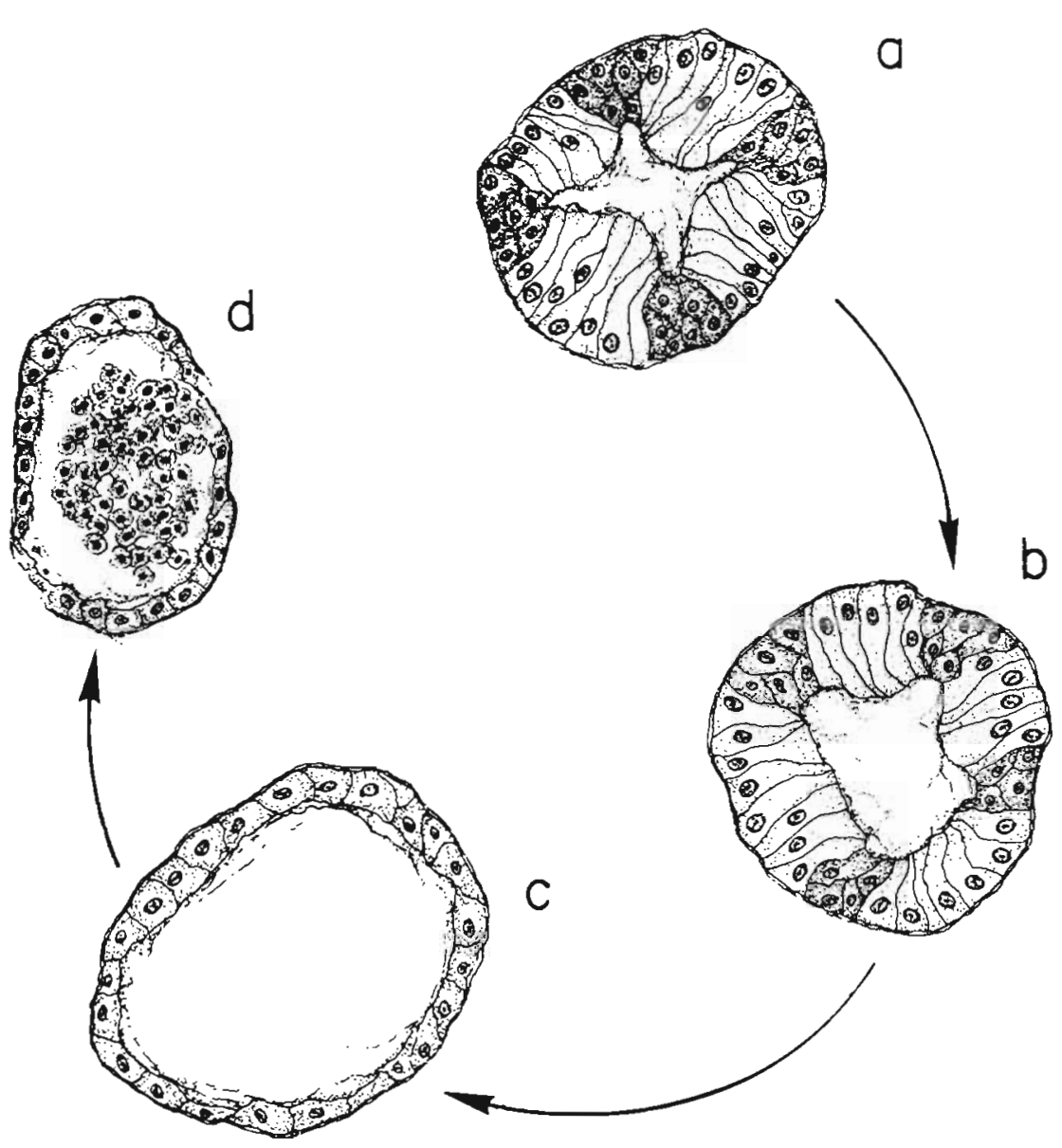

Fig. 8. Presumed sequence of possible stages leading from normal diverticula (a) to atrophic diverticula (b and c), and, in the absence of recovery, to epithelial cell death, sloughing, and necrosis (d). Compare to Fig. 6 \& 7 for actual histopathologic appearance of stages

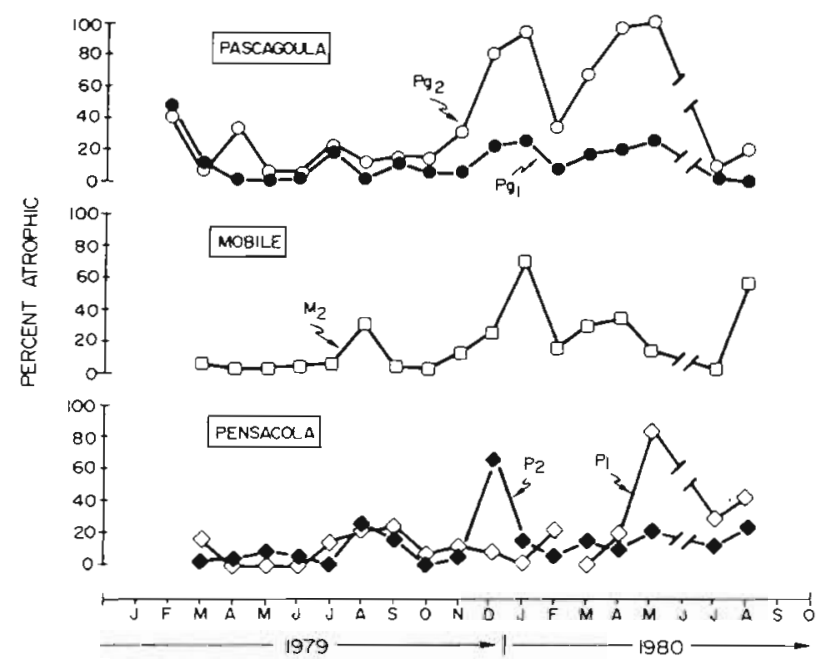

Fig. 9. Prevalence of digestive diverticular atrophy in oysters collected for over $1 \mathrm{yr}$ at monthly periods in the 3 estuaries. Each plotted line represents trends of prevalence (in percent oysters sampled with the condition) at a single site. In Mobile Bay, only a single oyster site (M2) was sampled. Note that at Site Pg2 in Pascagoula Harbor, up to $100 \%$ of the oysters had atrophic diverticular epithelia in Jan and May 1980
Blood cell proliferative disorders. Cellular proliferative disorders, usually involving presumed blood cells, have been reported, described, and characterized in oysters from around the USA (Couch 1969, 1970, Dawe 1969, Dawe \& Harshbarger 1969, Farley 1969, Farley \& Sparks 1970, Mix 1975, Frierman 1976, Scarpelli \& Rosenfield 1976, Couch \& Winstead 1979) and from around the world. Most investigators familiar with these disorders in oysters have recorded them as neoplastic equivalents. Presumed hemocytic proliferative disorders diagnosed in 24 oysters taken from 3 estuaries are shown in Table 1.

These cases represented a spectrum of the condition, ranging from apparent incipient, atypical, large-cell hemocytosis (Fig. 10a) to advanced proliferation in which sections showed almost complete replacement of vesicular connective tissue by the large atypical hemocytes (Fig. 10 \& 11). Several of the oysters with this disorder were also infected by various stages of the protistan pathogen Perkinsus marinum (Fig. 11c), as reported previously by Couch \& Winstead (1979). It is significant, perhaps, that 20 of the 24 cases of suspect neoplasia were found in oysters taken from Stations $\mathrm{Pg} 1$ and $\mathrm{Pg} 2$ in the Pascagoula Harbor area of Missis- 
sippi Sound. There were no apparent significant trends found in the seasonal occurrence of the cases for any of the estuaries.

Possible etiologies of the hemocytic disorder in oysters are uncertain. Recent reports (Chang et al. 1980) indicate that a retrovirus may cause a similar disorder in clams, but evidence for identity of any single etiology for the oyster blood cell disorder is incomplete (Couch et al. 1974, Mix 1979). Two recent reviews of aquatic animal neoplasia discuss the possible origin, nature, and etiology of the molluscan hemocytic neoplasms (Lauckner 1983, Couch \& Harshbarger 1985).

\section{Disorders and biological agents in fishes}

\section{Disease types}

Disorders found in fishes were classified as either infectious or noninfectious based on gross and histological examinations of fishes (individual cases) returned to the laboratory with suspect lesions. Criteria for the diagnoses of infectious disorders were (1) finding an infectious agent on, or in, tissues or (2) a lesion pathognomonic for a specific agent. Noninfectious lesions were diagnosed on the basis of lesion type and
Fig. 10. (a) Low magnification micrograph of cross section of oyster with incipient, hemocytic, proliferative disorder. Note focal basophilic centers or concentrations of proliferating hemocytes (arrows). Also note highly basophilic vesicular connective tissues among digestive diverticula; that basophilia results from high concentrations of atypical, proliferating hemocytes $(\times 10)$. (b) Higher magnification highlights invasive atypical hemocytes characteristic of blood cell proliferative disorder. Note that the hemocytes are filling large spaces as they proliferate in the blood sinuses of the vesicular connective tissue $(\times 73)$
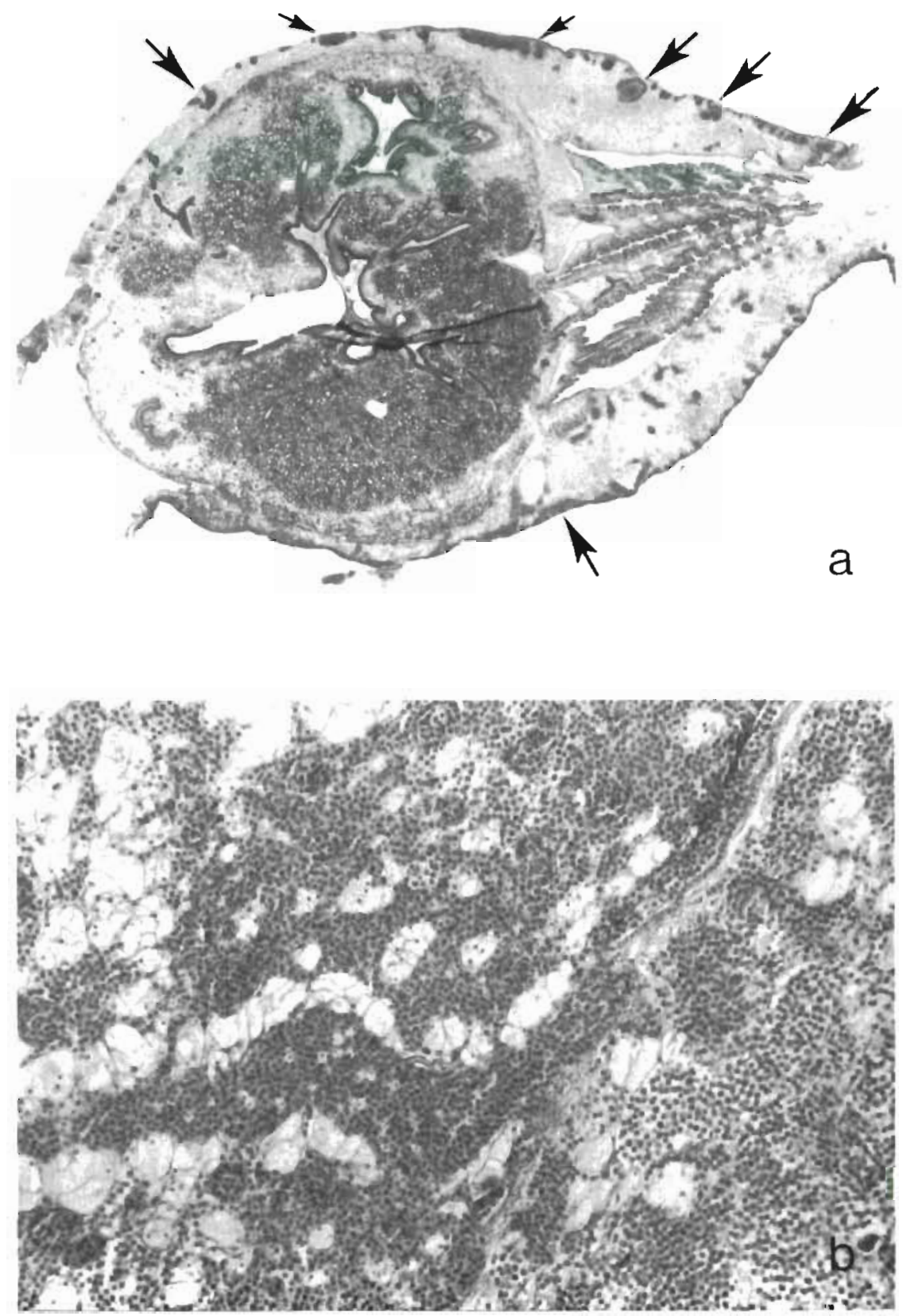

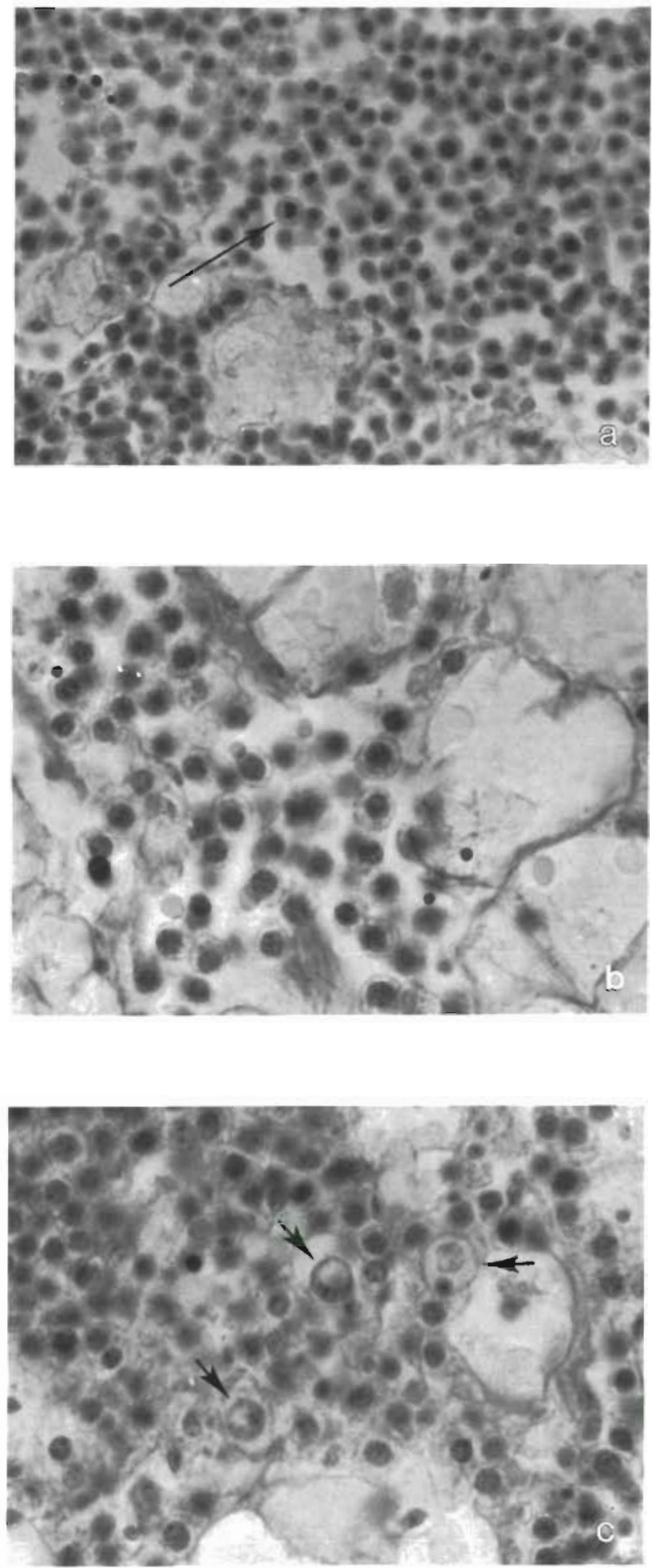

Fig. 11. (a) Oyster hemocytes characteristic of the blood cell proliferative disorder in Pascagoula Harbor oysters. Note the mitotic figure (arrow), and the high numbers of cells with relatively large nucleus and scant cytoplasm $(\times 650)$. (b) Atypical hemocytes in sinus surrounded by vesicular connective tissue cells. (c) Protistan parasite spores (arrows) of Perkinsus marinum in oyster with atypical, proliferative hemocytes. This represents a concurrent condition $(\times 870)$
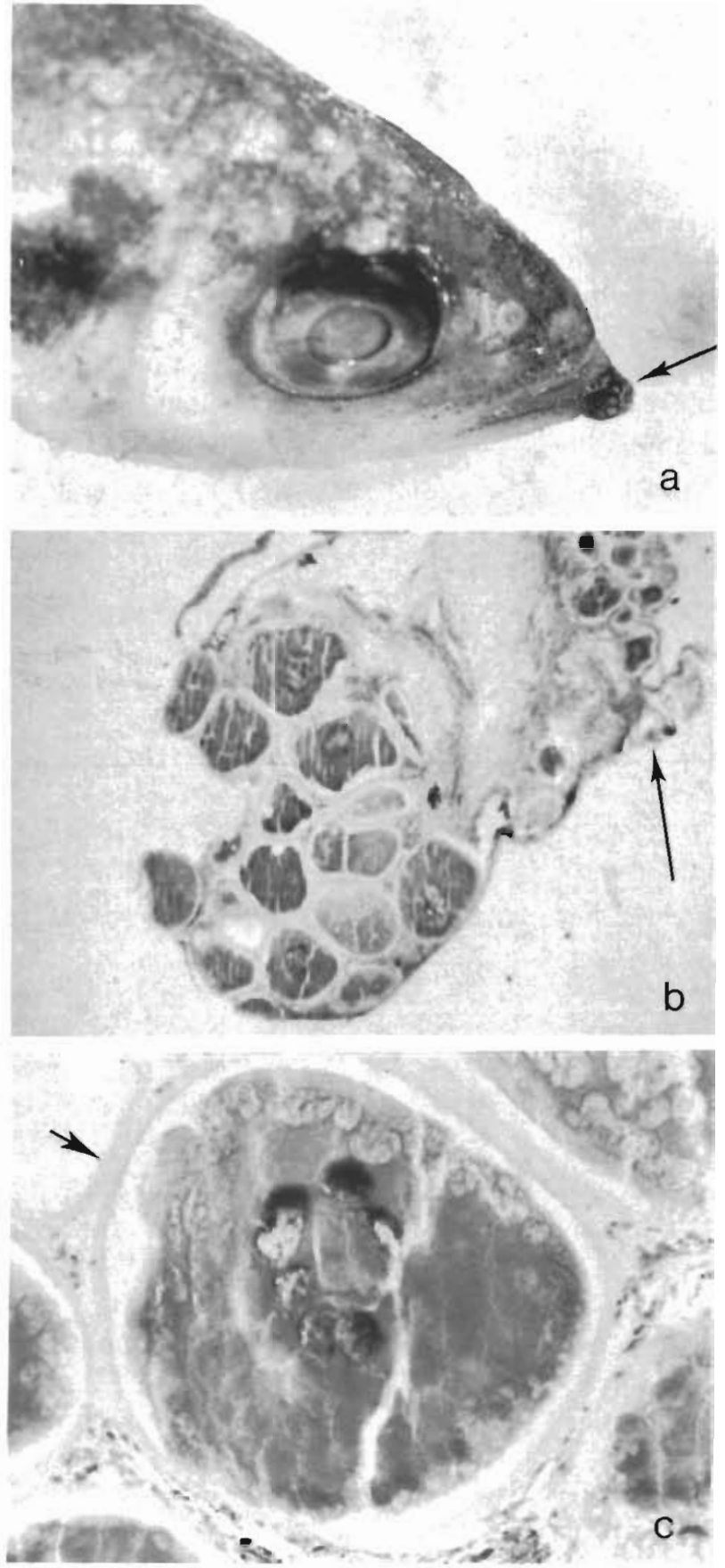

Fig. 12. (a) Bairdiella sp. Silver perch with lymphocystis tumor on apex of lower jaw. Fish was from Pascagoula Harbor. (b) Low magnification micrograph of lymphocystis lesion. Note that plane of section through whole lesion is filled by profiles of 16 or 17 hypertrophied cells infected with the virus. A small secondary lesion composed of a few other hypertrophied cells is also visible under cartilage of lower jaw (arrow) $(\times 18)$. (c) Single hypertrophied cell in lymphocystis lesion. This cell has characteristics pathognomonic of lymphocystis virus infection in fishes. Note the prominent hyaline capsule surrounding the cell (arrow). Note the virogenic stroma within the cytoplasm of the cell. The cell is enlarged (via hypertrophy) several hundred times that of its normal size $(\times 145)$ 
absence of an infectious agent or pathognomonic indication. This does not preclude the possibility that certain lesions diagnosed as noninfectious may have been vicariously caused by, or related to, infectious agents (e.g. delayed inflammatory response to previously present agent).

Some of the lesions found in fishes during this study have been described previously and relevant published papers will be cited. Original findings will be described in relevant detail in the next 2 sections and a discussion of fish disease prevalence will follow.

\section{Infectious disorders}

Lymphocystis hypertrophied cells (viral infection). Much work has been done on the cause (virus), description, and distribution of lymphocystis disease in fishes (Weissenberg 1965). This disease was first reported from Gulf of Mexico estuarine fishes by staff of the Gulf Coast Research Laboratory (Howse \& Christmas 1970, 1971, Overstreet \& Howse 1977). It is a natural infectious, viral disease of fishes.

Lymphocystis was the most frequently diagnosed, chronic, infectious disease in fishes from Mobile Bay
(6 cases) and Pascagoula Harbor (5 cases) during the $2 \mathrm{yr}$ of sampling. It was not found in fishes from Pensacola Bay.

The following species were found with lymphocystis: croaker 1 case, spot 2 cases, white trout 5 cases, silver perch Bairdiella sp. 1 case, sea trout Cynoscion nebulosus 1 case and flat sleeper Dormitator maculatus 1 case. Sciaenids apparently are the most susceptible to the disease, and infected individuals had white to gray lymphocystis lesions on flanks, heads, fins, and lower jaw (Fig. 12). The lesions are usually fatal to affected fish only if they are internal and interfere with vital function of normal tissues.

There were no seasonal trends reflected in the distribution of cases over time. Cases were found in each quarter of the 2 yr sampling period. It is important that no cases were found in any fishes from the Pensacola Bay stations, even though the same species (affected by the virus in Mobile and Pascagoula) were taken and examined in Pensacola.

Bacterial infections. Few bacteria are actually observed in the tissue of fishes. In the absence of laboratory culture studies, bacterial diseases in fishes usually are indicated by syndromes of gross morphological, behavioral, and histologic signs.

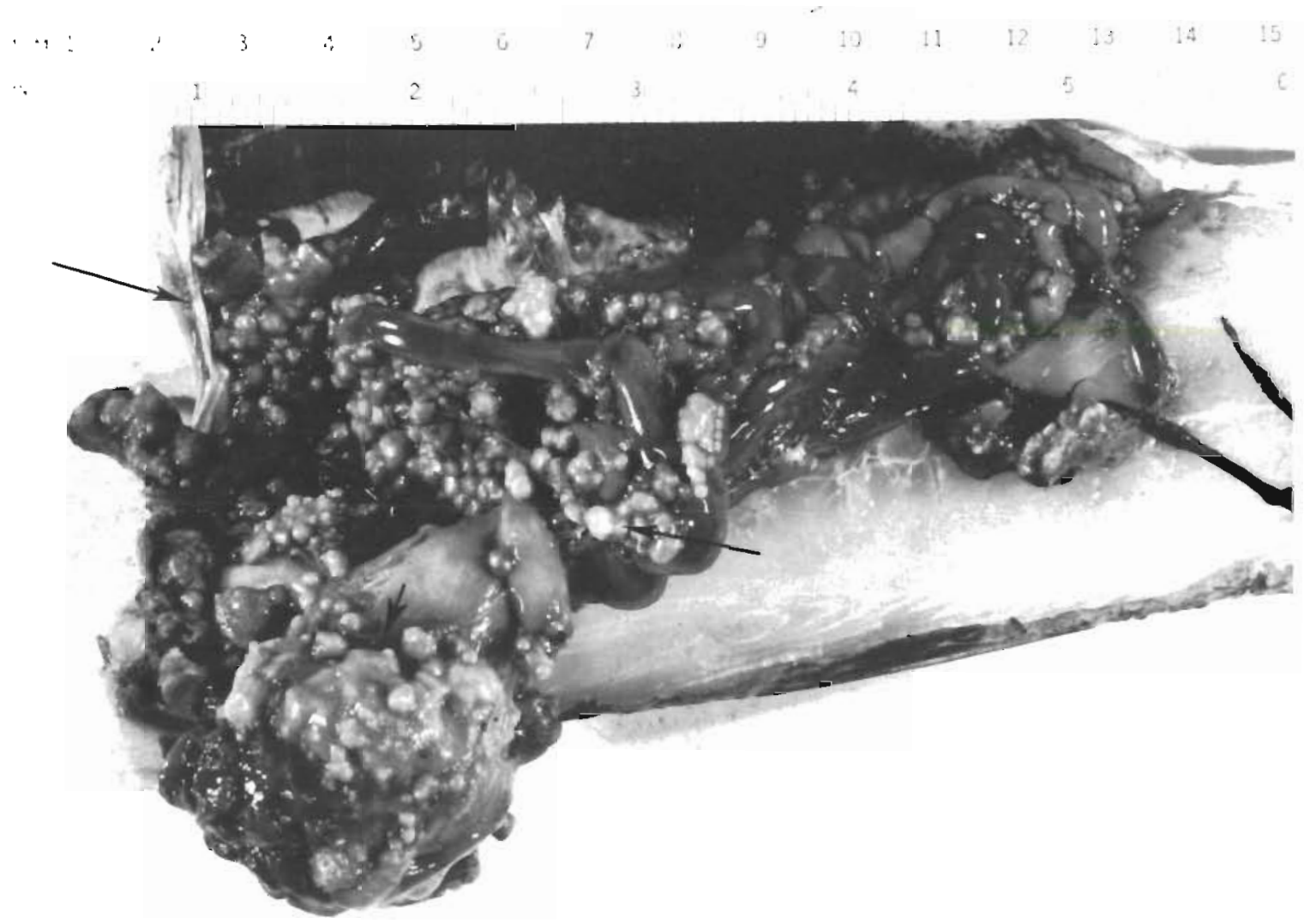

Fig. 13. Mugil cephalus. Granulomata (arrows) in mesenteries of the mullet. These chronic tubercles are caused by acid-fast bacteria, and probably represent fish tuberculosis $(\times 1)$ 
Granulomatous diseases. The most frequent indication of specific bacterial infections and disease found during this study was the occurrence of soft and hard tubercles (granulomata) in the mesenteries and in the visceral organs (Fig. 13) of fishes. These tubercles usually contained acid-fast bacilli, and may constitute fish tuberculosis.

The tubercles consisted of concentric masses of encapsulation tissue with centers containing necrotized bacilli and pigments (Fig. 14 \& 15). Most tubercles found within organs were soft, but some within organs and on mesenteries were partially or wholly calcified. Considerable amounts of necrotic pigments were associated with early and late tubercle formation (Fig. 15). They were found in the mesenteries of mullet Mugil cephalus (Fig. 13), 1 case; black drum Pogonias cromis, 2 cases; sheepshead Archosargus probatocephalus, 3 cases; and in the spleen of all these species (Fig. 14). All of the cases in the above listed species were found in fishes from Pascagoula Harbor stations. The majority of the cases were found in late summer and early fall samples.

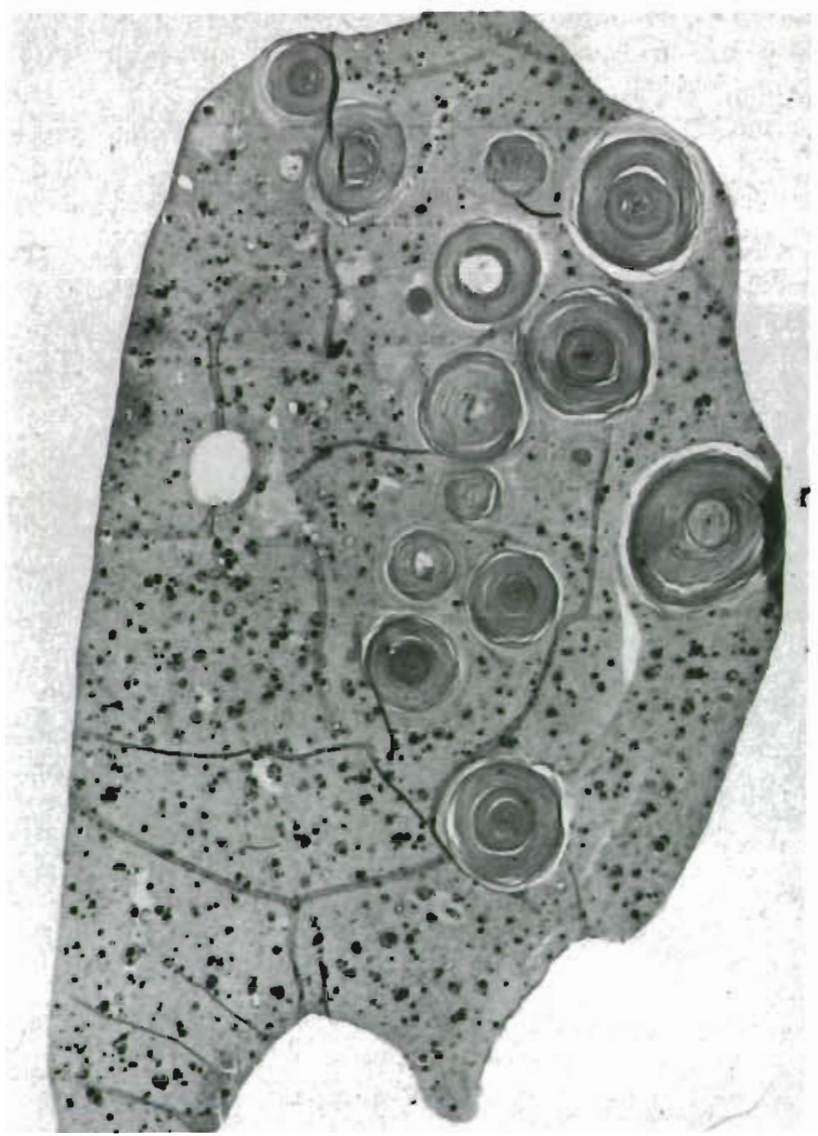

Fig. 14. Pogonias chromis. Spleen from the black drum filled with tubercles or granulomata caused by an acid-fast bacillus. The concentric structure is characteristic of calcified granulomata formed in some fishes. Remnants of acid-fast bacteria are found in the centers of the tubercles $(\times 17)$
All cases collected during this study were found only through internal examination of fishes. External signs were not severe enough to indicate infection which, in most cases, based on the numbers of tubercles and severity of internal tissue damage, were quite advanced (Fig. 14).

Nonspecific inflammation. Fifty-one cases, in different species of fishes, of inflammatory tissue reactions were found in sections of tissues with gross inflammatory lesions. Most of these cases were characterized by heavy infiltrates of white cells (lymphocytes, granulocytes, or macrophages) into a local area of an organ or tissue (Fig. 16). They were not classical granulomatous reactions, as described in the previous section. A few of the cases were characterized by deposition of connective tissues at foci. Occasionally, some coccoid and bacilloid bacteria were observed in these sections, but
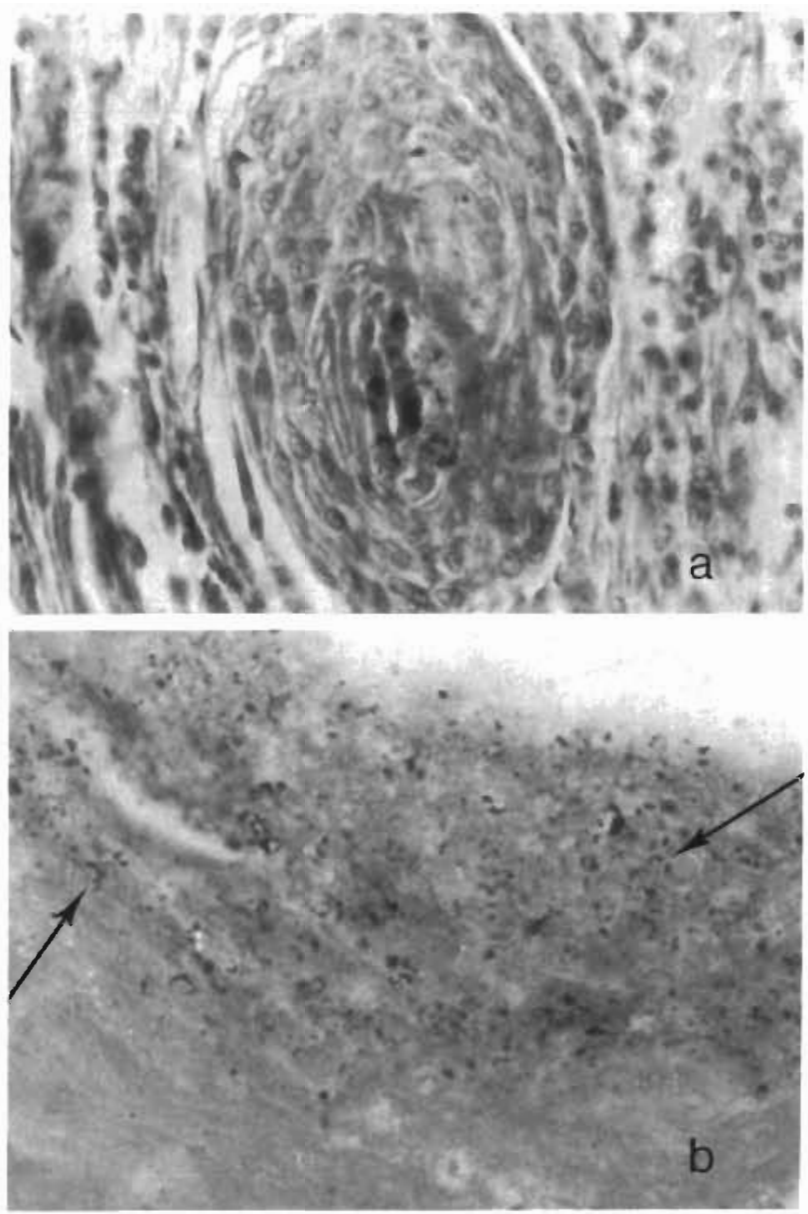

Fig. 15. (a) Soft, noncalcified tubercle representative of the other type (not hard) granuloma associated with fish tuberculosis or pseudotuberculosis. This was found in the liver of a sheepshead (Archosargus probatocephalus) from Pascagoula Harbor $(\times 700)$. (b) Acid-fast stain of section through hard (calcified) tubercle in spleen of black drum. Note the acidfast, stained bacterial remains (arrows) and other pigments indicative of agents of fish tuberculosis $(\times 930)$ 
there were no categorically clear relations evident between the agents and the cellular responses observed. I term this type of lesion nonspecific inflammation because it most probably is caused by the presence of an infectious microbial agent or irritant chemical agent, but specific identity of the agent is impossible.

Nonspecific inflammatory responses observed did not occur in frequencies or seasonal patterns that indicated a seasonal trend in prevalence. A few cases were found in different tissues and fishes from each estuary, with no single estuarine station having a predominance of fishes with such lesions.

Fungal infections. The only specifically identified lesions associated with internal fungal infections in fishes were 2 cases of fishes with Ichthyophonus from Mobile and Pascagoula stations. Ichthyophonus is thought to be a phycomycete fungus (Sindermann 1954. Sprague 1965, 1977), and has been found in many species of teleosts (Amlacher 1970) from marine waters. Only 1 spot and 1 sea catfish were found infected with Ichthyophonus sp. The internal lesions in these fish were striking because of the extensive

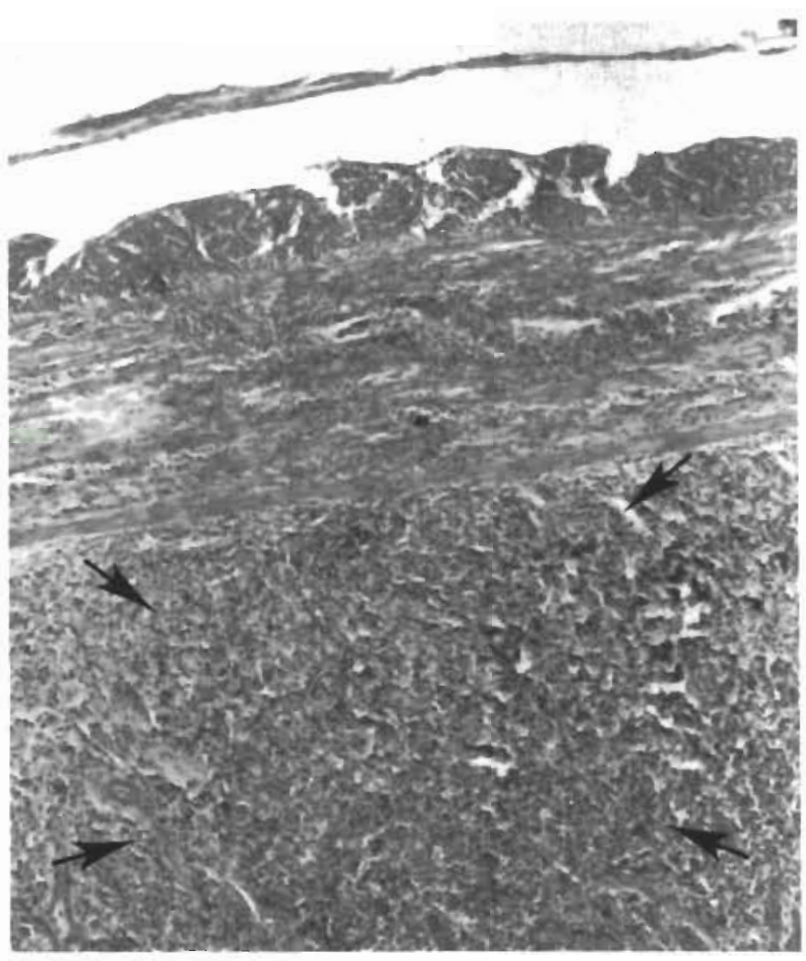

Fig. 16. Nonspecific inflammatory response in the submucosal region of the small intestine of a black drum (fish). Note the concentration of lymphocytes in the lamina propria region and above the muscularis layer of the tract (arrows). No etiologic agent could be associated with this lesion, but it is characteristic of chemical injury, and bacterial and/or viral invasion. This type of lesion is sometimes visible as reddish or white enlargements in the internal organs of fishes $(\times 100)$ granulation tissue, caused by the plasmodia and hyphae of the fungus, replacing much vital tissue of hosts (Fig. 17).

There was no evidence collected in this survey that suggests epizootic outbreaks of Ichthyophonus in fishes along the Gulf Coast. It is of some interest that the 2 cases of advanced Ichthyophonus infections, 1 diagnosed in sea catfish and 1 in the spot, were in cooler periods of the year (Nov and Feb). Not enough data on this infectious agent are available to permit speculation on its role in fish health on the Gulf Coast, but its record as an epizootic killer of fishes in northern marine waters is well documented (Sindermann 1954). It is possible that outbreaks of the fungus could occur in colder periods of the year in fishes along the Gulf Coast. This possibility constitutes the basis for further specific studies in stressed and nonstressed fishes in the Gulf area.

Protozoan infections. Certain Protozoa are wellknown pathogens of marine and freshwater fishes. Species of myxosporida, microsporida, peritrichous ciliates and coccidia are examples of protozoans that are pathogenic in fishes (Hoffman 1967, Amlacher 1970, Snieszko 1970, Ribelin \& Migaki 1975).

Histological sections of fish tissues examined during this study revealed 38 cases of internal infections by Protozoa. Several cases of myxosporidian infections were found in fishes from each estuary. There was no evidence of epizootic occurrences of protozoan diseases detected with the limited level of sensitivity of our necropsy procedure. Internal, microscopic infections could have gone undetected. Overstreet \& Howse (1977) reported numerous non-epizootic protozoan infections in various species of fishes in Mississippi Sound from the vicinity of Biloxi, Mississippi. No estuarine or seasonal trends were detected for protozoan infections.

It is unknown if pollutants enhance most protozoan diseases in fishes, and no evidence was collected in this study to indicate that pollutant-induced stress could have enhanced disease of fishes caused by Protozoa. Lack of evidence from this study does not preclude the possibility that certain protozoan-caused diseases may be influenced by pollutant conditions or water quality of coastal areas.

Helminths in fishes. Both parasitic flatworms and roundworms occur commonly in different tissues of most teleosts. Twenty-two cases of encycsted metacercaria of trematodes causing visible cysts or tumor-like lesions were found beneath the epidermis, in the musculature, or in the internal organs in species of teleosts during this study. Likewise some sciaenid fishes from most coastal regions in the northern Gulf of Mexico (i.e. spotted sea trout Cynoscion nebulosis) were found to be $100 \%$ infested with larval tapeworms in their 

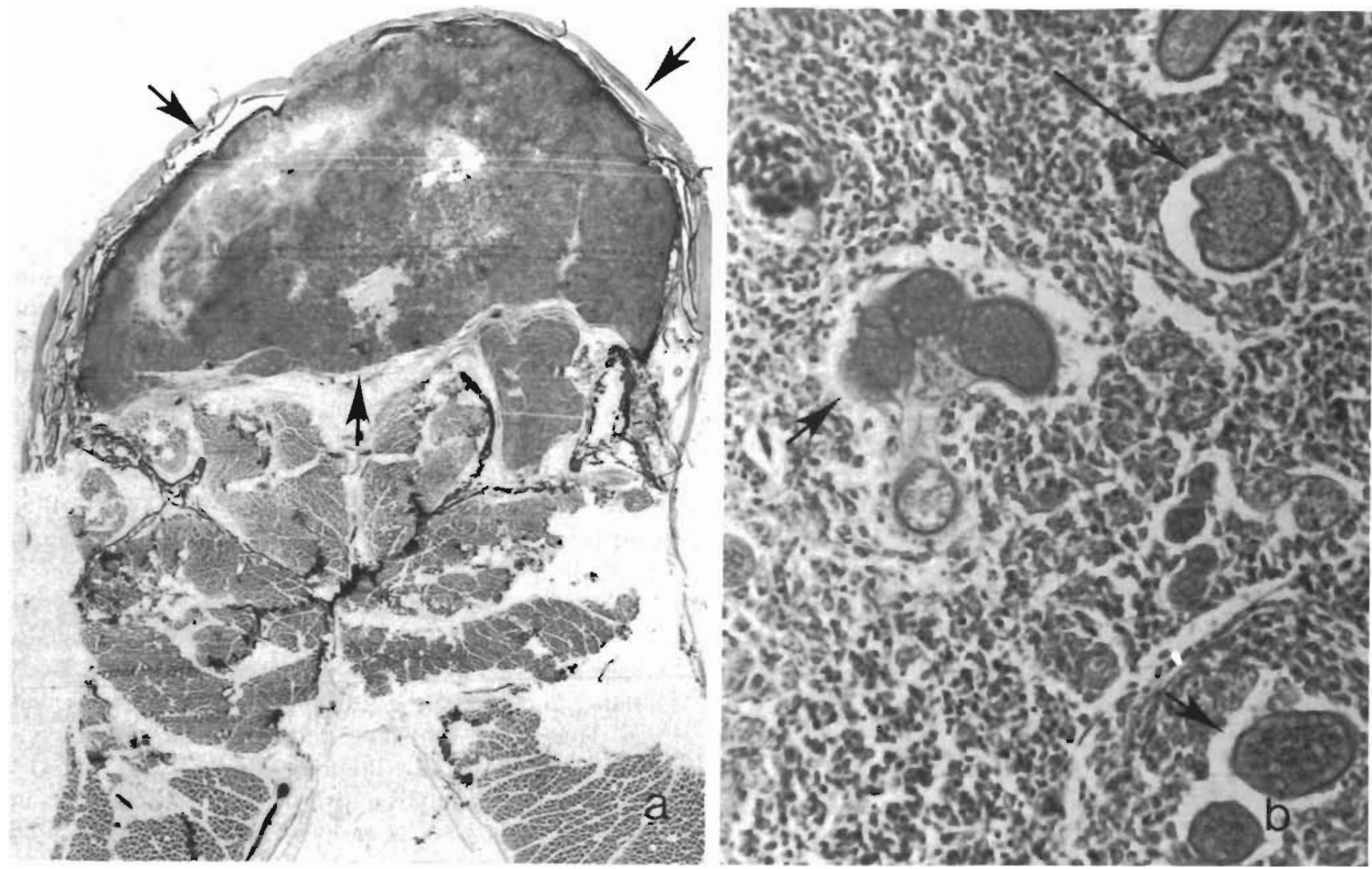

Fig. 17. Leiostomus xanthurus. (a) Cross section of body of small spot with pseudotumor (arrows) in ventral aspects (near isthmus) consisting of granulation tissue and Ichthyophonus parasites $(\times 7)$. (b) Granulation tissue surrounding Ichthyophonus stages in the large lesion. Note several different stages of the parasite (arrows) $(\times 900)$

musculature. Because most of these helminths are common, natural parasites with complex, indirect, lifecycles, it is not yet obvious that they may be used as indicators of pollutant effects, either vicariously or directly. No trends of helminth infestation of fishes were found that would indicate environmentally related influences at any of the sample sites or among estuaries.

\section{Noninfectious disorders}

During this study, only 2 major lesion types in fishes were found that could be easily classified as noninfectious. These 2 categories are (1) lesions that resulted from apparent traumatic injury to fishes, (2) tumor-like lesions diagnosed as neoplasms.

Traumatic injury and related lesions. Though highly significant to the injured individual, these types of lesions stem from truly random, physical events (e.g. net and predator injury) and have little value for indicating an environmental trend in the health of fish populations.

The major kinds of trauma indicated in fishes from this study apparently resulted from predator-prey interactions (bite wounds), net-inflicted abrasions, and hook lesions in mouths or on jaw structures. These lesions will not be described here because of their lack of association with pollutant activity.

Neoplasms (tumors) in fishes. Relatively few true neoplasms were found in the thousands of fishes examined. The tumors described here came from 2 major sources: (1) from trawl catches during the regular sampling periods of the estuarine stations; and (2) from citizens who responded to a brochure, circulated publicly, requesting tumor-bearing specimens to be brought to our laboratory from the 3 estuaries studied.

Most superficial tumors found on fishes collected during regular trawl sampling periods were found by histopathological study to be actually nonspecific inflammatory reactions, lymphocystis infections, and parasitic infections with granulation response tissue (Fig. 17), or scar tissue resulting from traumatic injury. Some other authors have reported similar results following surveys and careful, subsequent histopathology of fish lesions from specific coastal regions elsewhere (Hard et al. 1979).

Table 2 lists the lesions thought to be neoplasms and 
Table 2. Fish neoplasms found (1978-1980)

\begin{tabular}{|c|c|c|c|}
\hline $\begin{array}{l}\text { Fish species, } \\
\text { no. found, date }\end{array}$ & Pensacola & Mobile & Pascagoula \\
\hline $\begin{array}{l}\text { Spotted sea trout } \\
\text { (Cynoscion nebulosus) } \\
1 \text { specimen } 11 \text { Nov } 78\end{array}$ & $\begin{array}{l}\text { White mass on internal } \\
\text { aspect of body wall near air } \\
\text { bladder. Diagnosis: } \\
\text { fibrolipoma (Fig. 18) }\end{array}$ & & \\
\hline $\begin{array}{l}\text { Gulf killifish (Fundulus } \\
\text { grandis), } 3 \text { specimens } \\
21 \text { Feb } 79\end{array}$ & & $\begin{array}{l}\text { Large multicentric, multi- } \\
\text { colored masses on body. } \\
\text { Diagnosis: chromatophoro- } \\
\text { ma (Fig. 19) }\end{array}$ & \\
\hline $\begin{array}{l}\text { Largemouth bass } \\
\text { (Micropterus salmoides) } \\
1 \text { specimen } 1 \text { Apr } 79\end{array}$ & & $\begin{array}{l}\text { Large horny mass protruding } \\
\text { ventrally from isthmus. } \\
\text { Diagnosis: osteochondroma } \\
\text { (Fig. 20) }\end{array}$ & \\
\hline $\begin{array}{l}\text { Croaker } \\
\text { (Micropogon undulatus) } \\
1 \text { specimen } 5 \text { Jun } 79\end{array}$ & $\begin{array}{l}\text { Horny mass inside mouth } \\
\text { above right mandible. } \\
\text { Diagnosis: osteoma } \\
\text { (Fig. 21a) }\end{array}$ & & \\
\hline $\begin{array}{l}\text { Killifish } \\
\text { (Fundulus similis) } \\
1 \text { specimen } 1 \text { Sep } 80\end{array}$ & & & $\begin{array}{l}\text { White to yellow mass on } \\
\text { pelvic fin and progressing } \\
\text { to body. Diagnosis: Highly } \\
\text { invasive epidermal cell } \\
\text { carcinoma with numerous } \\
\text { mitoses (Fig } 21 b, c, d \text { ) }\end{array}$ \\
\hline
\end{tabular}

species of fishes found with neoplasms from August 1978 to August 1980.

Description of neoplasms in fishes: Fibrolipoma in spotted seatrout. A single specimen was collected from Pensacola Bay with a large white mass on the internal aspect of the body wall adjacent to and slightly below the air bladder. The mass was several $\mathrm{cm}$ long and wide and occupied approximately one-fifth of the abdominal cavity. Histology revealed that most of the mass consisted of lipocytes (Fig. 18a), but portions also consisted of trabeculae of fibers and fibroblasts or fibrocytes (Fig. 18b). The tumor was not invasive to the body wall, air bladder, kidney or other organs. Tentative diagnosis is fibrolipoma.

This is apparently a rare tumor and there is no evidence that it is related to environmental factors. Tubiash \& Hendricks (1973) reported a similar tumor in the weakfish Cynoscion regalis from Virginia.

Chromatophoroma in Gulf killifish. Four tumorbearing specimens of the Gulf killifish Fundulus grandis were collected February 21, 1979, by personnel of the Claude Peteet Mariculture Center of Gulf Shores, Alabama and presented to our laboratory for study. The fish were taken from flowing water culture ponds $(1 / 4$ acre $)$, fed water from the intracoastal waterway near Mobile Bay, and were observed in aquaria at our laboratory for several weeks prior to necropsy. Though the fish were not taken at one of our stations, they were held most of their lives in water similar in quality to Mobile Bay waters. These tumors are described in some detail because they are new for this species and may be dermal in origin, suggesting a possible environmental causation. The tumor-bearers were older, larger $F$. grandis (12 to $16 \mathrm{~cm}$ ) maintained at the mariculture center. Subsequent to finding the 4 tumorbearing fish, taken from 2 different samples several months apart in 1978-1979, over 6000 large $F$. grandis from the same ponds were examined grossly for recovery of other possible tumor-bearers without success.

Tissue specimens were taken from all tumors. Careful examination of the entire fish was completed in 3 or 4 cases. Particular attention was given to musculature and internal organs underlying or adjacent to tumors.

Three of the 4 had heavily pigmented, multicolored tumors (white, black, gray, red, orange, yellow) on different parts of their bodies. Tumors protruded through and replaced epidermis, dermis and connective tissues and had convoluted surfaces with pigments variously distributed in the surfaces (Fig. 19a).

Tumors over $2 \mathrm{~cm}$ in length were found on the caudal peduncle and head of 2 fish; smaller tumors $(<1 \mathrm{~cm})$, on the back, flanks and head of all 3 fish (Fig. 19a). The fourth fish had a white tumor on its caudal fin that appeared to be bony in origin and had 
Numbers of diseased fishes

Tables 3 to 5 present data on the numbers of fish necropsied by estuary, and the total found with significant evidence of disease from each estuary (total of all stations from each estuary). The necropsy procedures used in this study resulted in finding 137 overt cases of probably chronic disease in over 11,000 fishes examined. Fig. 22 permits rapid visual comparison of the total number of distinct disease cases per 1000 fish necropsied for each of the stations in each estuary

Fig. 22 indicates that fishes from Pascagoula Harbor Stations Pg1, Pg2, and Pg4 have higher prevalences of disease than fishes from either of the other 2 estuaries (Mobile and Pensacola). Indeed, the average disease rate for Pascagoula Harbor fishes is 21.2 per 1000 fishes examined whereas it is 9.2 per 1000 for the next highest, the Mobile estuary

There is little doubt, due to our inability to carry out complete histological examination of all tissues from each fish necropsied during this study, that cryptic lesions or disorders were missed in many fishes. But our aim was to search for obvious chronic lesions in the field. As mentioned in the methods section, only fishes with apparent chronic lesions detected grossly by necropsy were returned to the laboratory for complete histological examination and identification. Therefore, these data lead to a very conservative estimation of disease prevalence in the 3 estuaries. The data suggest, but do not conclusively demonstrate, that fishes in Pascagoula Harbor water were at higher disease risk generally than were those in Mubile or Pensacola Bay
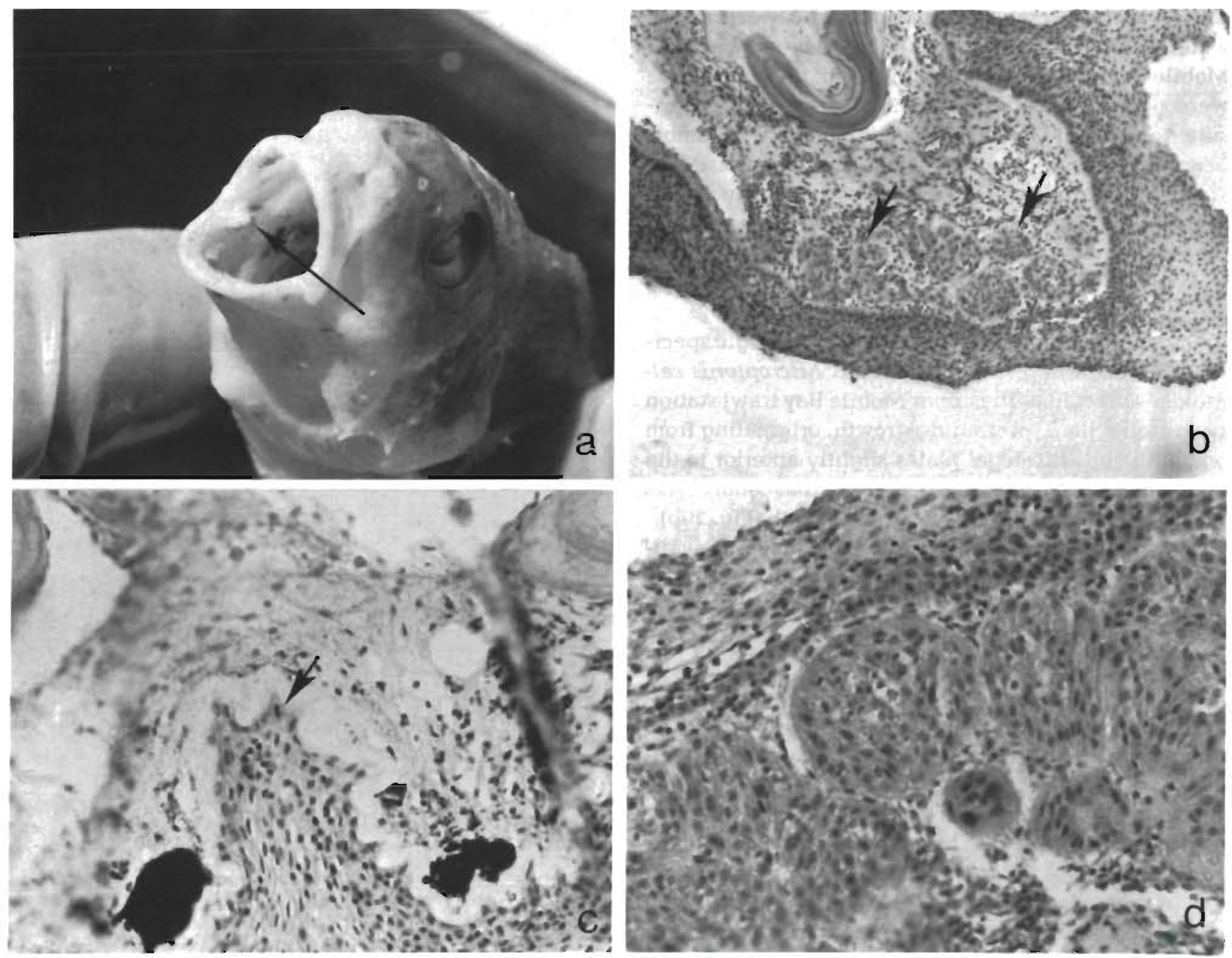

Fig. 21. (a) Micropogon undulatus. Croaker from Pensacola Bay with bony tumor protruding at inner corner of mouth (arrow), diagnosed as osteoma. (b) Fundulus similis. Section through white to yellowish mass on pelvic fin of the killifish Note the thickened epidermis and pearl-like (multicentric) formations beneath the epidermis (arrows) also illustrated at higher magnification in (d). This growth was diagnosed as an invasive epidermal cell carcinoma $(\times 70)$. (c) Peg of epidermal cells pressing dermis in killifish tumor from (b). Note mitotic figure (arrow) in peg $(\times 890)$. (d) Pearl-like formations (multicentric) of cells resulting from penetration of neoplastic epidermal cells beneath the dermis in the killifish $(\times 890)$ 
Table 3. Prevalence of diseased fishes at Pensacola stations

\begin{tabular}{|c|c|c|c|c|c|c|c|c|}
\hline & \multicolumn{2}{|c|}{ P 1} & \multicolumn{2}{|c|}{ P2 } & \multicolumn{2}{|c|}{$\mathrm{P}_{4}$} & \multicolumn{2}{|c|}{ Totals } \\
\hline & $\mathrm{Nec}^{1}$ & $\mathrm{Dis}^{2}$ & $\mathrm{Nec}$ & Dis & $\mathrm{Nec}$ & Dis & $\mathrm{Nec}$ & Dis \\
\hline $\begin{array}{l}\text { Totals } \\
\text { Aug } 78 \text {-Aug } 80\end{array}$ & 1,812 & 10 & 1,622 & 10 & 749 & 9 & 4,183 & 29 \\
\hline $\begin{array}{l}\text { No. Dis } \\
\text { Cases } / 1000\end{array}$ & \multicolumn{2}{|c|}{5.5} & \multicolumn{2}{|c|}{6.2} & \multicolumn{2}{|c|}{12.0} & \multicolumn{2}{|c|}{6.9} \\
\hline \multicolumn{9}{|c|}{$\begin{array}{l}{ }^{1} \text { Nec }=\text { Necropsied } \\
2 \text { Dis }=\text { Possessed } 1 \text { or more lesions or indication of infectious or noninfectious disorders as qualitatively described in } \\
\text { this paper }\end{array}$} \\
\hline
\end{tabular}

Table 4. Prevalence of diseased fishes at Mobile stations

\begin{tabular}{|c|c|c|c|c|c|c|c|c|}
\hline & \multicolumn{2}{|c|}{ M1 } & \multicolumn{2}{|c|}{ M2 } & \multicolumn{2}{|c|}{ M4 } & \multicolumn{2}{|c|}{ Totals } \\
\hline & $\mathrm{Nec}$ & Dis & $\mathrm{Nec}$ & Dis & $\mathrm{Nec}$ & Dis & $\mathrm{Nec}$ & Dis \\
\hline $\begin{array}{l}\text { Totals } \\
\text { Aug } 78 \text {-Aug } 80\end{array}$ & 1,592 & 9 & 1,772 & 13 & 1,403 & 22 & 4,767 & 44 \\
\hline $\begin{array}{l}\text { No. Dis } \\
\text { Cases } / 1000\end{array}$ & \multicolumn{2}{|c|}{5.7} & \multicolumn{2}{|c|}{7.3} & \multicolumn{2}{|c|}{15.7} & \multicolumn{2}{|c|}{9.2} \\
\hline
\end{tabular}

Table 5. Prevalence of diseased fishes at Pascagoula stations

\begin{tabular}{|c|c|c|c|c|c|c|c|c|}
\hline & \multicolumn{2}{|c|}{$\mathrm{Pg} 1$} & \multicolumn{2}{|c|}{$\operatorname{Pg} 2$} & \multicolumn{2}{|c|}{$\mathrm{Pg} 4$} & \multicolumn{2}{|c|}{ Totals } \\
\hline & $\mathrm{Nec}$ & Dis & $\mathrm{Nec}$ & Dis & $\mathrm{Nec}$ & Dis & $\mathrm{Nec}$ & Dis \\
\hline $\begin{array}{l}\text { Totals } \\
\text { Aug } 78-\text { Aug } 80\end{array}$ & 1,047 & 21 & 1,196 & 28 & 794 & 15 & 3,037 & 64 \\
\hline $\begin{array}{l}\text { No. Dis } \\
\text { Cases } / 1000\end{array}$ & \multicolumn{2}{|c|}{20.1} & \multicolumn{2}{|c|}{23.4} & \multicolumn{2}{|c|}{18.9} & \multicolumn{2}{|c|}{21.1} \\
\hline
\end{tabular}

waters. All of the granulomatous lesions (presumptive tuberculosis), many of the lymphocystis infections, and many of the nonspecific inflammatory lesions were from Pascagoula Harbor fishes. Two stations, M4 in Mobile Bay and P4 in Pensacola Bay were, perhaps, exceptions to this generality (Fig. 22). Both of these stations provided fish samples with higher prevalences of disease than the average prevalence of their respective estuaries. It is of interest to note that Stations P4 and M4 are closest, in their respective estuaries, to major river effluents and human industrial activities.

\section{DISCUSSION}

The goals of this study were to determine disease prevalences and to describe chronic diseases or disorders of oysters and fishes in 3 distinct estuaries on the northern Gulf of Mexico. Though no direct link was established between specific chemicals or agents and disease conditions, oysters and fishes appeared to be at higher general disease risk in Pascagoula Bay than in Mobile Bay and Pensacola Bay during the study (Aug 1978 to Aug 1980). Two disease conditions in oysters appeared to be more prevalent in Pascagoula oysters than either in Mobile Bay or Pensacola Bay oysters: (1) digestive gland epithelial atrophy, (2) proliferative blood cell disease (a probable hemic neoplasm). Fishes also appeared to be at higher general disease risk in Pascagoula Bay than either in Mobile Bay or Pensacola Bay, based on total numbers of fishes diagnosed for disease per 1000 fishes examined.

The base-neutral organics data generated in a parallel chemical monitoring study indicate, in summary, that Pascagoula Bay has a higher and more varied general organics burden than Pensacola Bay and that the general organics burden of Mobile Bay is intermediate between those of the other 2 bays (Laseter \& 


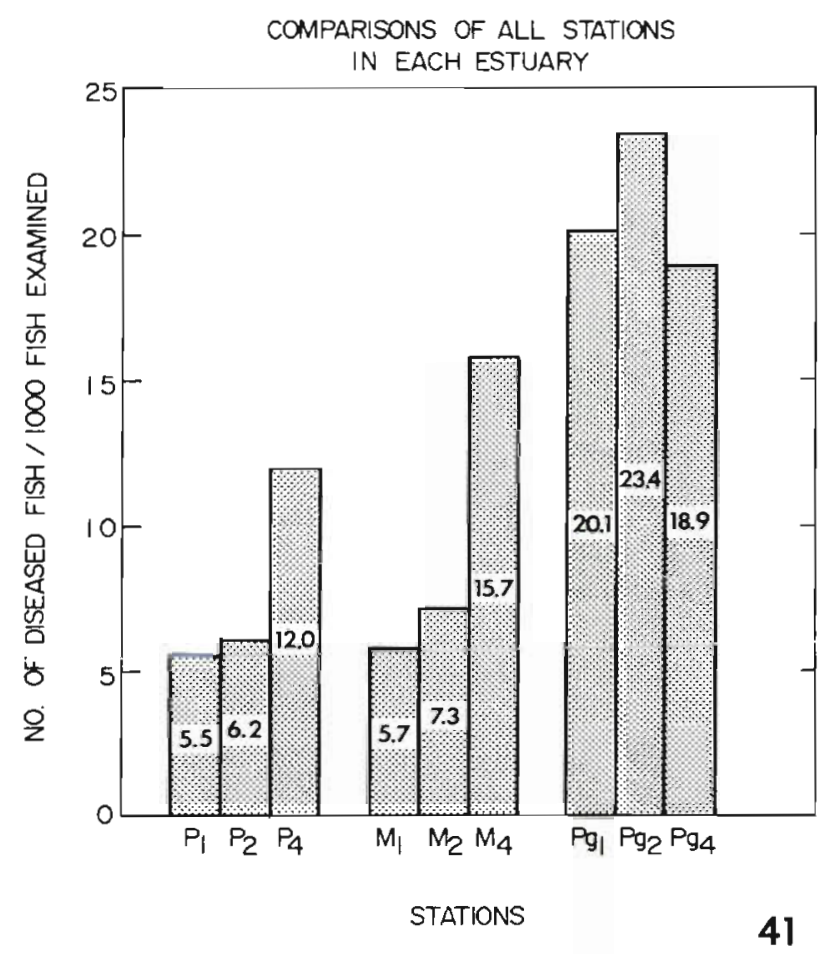

Fig. 22. Prevalence of diseased fishes at each fish sampling site in all the estuaries studied. Prevalence is expressed as number of diseased fishes per 1000 examined, determined from the totals for 25 mo of sampling

Lawler 1982). All 3 bays appear to receive similar concentrations of measured polycyclic aromatic hydrocarbon (PAH) (Laseter \& Lawler 1982). The major source of PAH's in all 3 bays probably is pyrolysis of fossil fuels or other combustion products. Pascagoula Bay showed the only occasional indication of direct inputs of fossil fuels, perhaps due to some petroleum spills (leakage-seepage).

Data from Laseter \& Lawler (1982) also indicate that each of the 3 bays receives inputs of organic pollutants of mixed anthropogenic origin. All 3 bays appear to receive a similar variety of industrial organic contaminants and also to have similar concentrations for these contaminants. There were, however, indications that Pascagoula Bay may be receiving a greater variety of industrial organic contaminants than the other 2 bays (Laseter \& Lawler 1982). All 3 bays are in close proximity to relatively large and growing population centers and rural farmlands. It is likely, therefore, that sources of organic pollutants include: inputs from the industries along the banks of the bays, urban and rural air particulate matter fallout, terrestrial runoff, and ship traffic.

Based on the results of this study, the following specific and general recommendations are made:

(1) Using the study as a base line, or its results as a point of departure, future efforts in the same or in similar estuaries should be more limited in area and species studied in order to link more precisely cause and effect between specific measured contaminants and specific diseases.

(2) Results of this study indicated a very low tumor prevalence in fishes at the stations and times sampled $1<1$ per 1000 fishes examined). The lack of tumor epizootics in fishes suggests low risks to fishes at those stations due to carcinogens. Future studies should be retrospective in regard to neoplasia as an indicator of carcinogen contaminations, i.e. detailed studies should be based on an a priori indication of higher tumor prevalence in certain species at certain sites.

(3) Fishes are mobile while oysters are sessile and hence more chronically exposed to localized contaminants. However, some fish infectious diseases namely, granulomatous disease and lymphocystis could be monitored in estuarine fish populations to determine if their pathogenesis is influenced by pollutant contamination, i.e. contaminant-induced loss of disease resistance.

(4) Oysters may be more sensitive indicators of localized environmental contamination than many fishes, and may provide a more representative response to focal contamination in coastal regions (Balouet \& Poder 1981). Oysters can be introduced conveniently into study areas and monitored. Future studies should include careful monitoring in oyster populations for tissue and physiologic changes indicative of chemically induced stresses. The following oyster histopathoses are worthy of further examination as bioindicators of the presence of possible chemical contaminants: (a) digestive gland epithelial atrophy; (b) blood cell proliferative disorders.

(5) Several infectious diseases in oysters and fishes detected during this study were either new or rarely studied in the northern Gulf Region. The 2 most important ones, in terms of possibly related effects to biota and human health, are: (a) rickettsia found in digestive gland cells in oysters; (b) Ichthyophonus fungus described in 2 species of fishes. Studies should be initiated on the roles that these diseases play in oyster and fish health along the northern Gulf and in other estuaries worldwide.

(6) Results of this study suggest that though far from being pristine, the estuaries studied were not severely unhealthy environments at the time the biota were sampled. However, because predictions have been made that the Gulf Coastal Plain of the southeastern US will probably be the fastest growing region in the nation in the next decade, this study and another (Overstreet \& Howse 1977) provide base lines, points of departure and comparison for studies that should be made, periodically, on the health of coastal biota in 
relation to the increasing impact of population and industrial growth.

Acknowledgements. This study could not have been conducted without the strong effort of John Wright and Victor Mitchell, biologists, who completed the field collections, field necropsies, preparation of field samples, and field reports on specimens and sites. James Winstead prepared and screened sections of oysters and fishes (several thousand specimens) in preparation for final diagnoses of disorders. Lee Courtney, Steve Foss, and Susan Martin prepared various samples for final analyses during the 2 yr study. Steve Foss assembled the figures and plates, and Lee Courtney drew some of the figures. Dr. William Hawkins provided the electron micrograph of the oyster rickettsia. This study was funded through the Interagency Collaborative Program (NCI/USEPA) on Environmental Carcinogenesis (Project No. 3) directed by Dr. Herman Kraybill, NCI.

\section{LITERATURE CITED}

Amlacher, E. (1970). Textbook of fish diseases. T.F.H. Publications, New Jersey

Balouet, G., Poder, M. (1981). Effets biologiques de la pollution par les hydrocarbures de l'Amoco Cadiz sur l'ostreiculture en Bretagne Nord. In: Amoco Cadiz. Consequences d'une pollution accidentelle par les hydrocarbures. Actes Colloque C.N.E.X.O., p. 703-714

Buchanan, J. S. (1978). Cytological studies on a new species of rickettsia found in association with a phage in the digestive gland of the marine bivalve mollusc, Tellina tenuis (Da Costa). J. Fish Dis. 1: 27-43

Chang, P. W., Oprandy, J. J., Brown, R. S., Dawson, G. T., Appledorn, R. S., Yates, V. J. (1980). Viral etiology of a transmissible hematopoietic type of molluscan neoplasia. Proc. 80th Ann. Meet. Am. Soc. Microbiol., p. 208

Comps, M., Tige, G., Duthoit, J., Grizel, H. (1977). Microorganisme de type rickettsien chez les Huitres Crassostrea gigas et Ostrea edulis. Haliotis 8: 317-321

Comps, M., Raibault, R. (1978). Infection rickettsienne de la glande digestive de Donax trunculus L. Sci. Peche 281: $11-12$

Cooper, R. C., Keller, C. A. (1969). Epizootiology of papillomas in English sole, Parophrys vetulus. Natl. Cancer Inst. Monogr. 31: 173-185

Couch, J. A. (1969). An unusual lesion in the mantle of the American Oyster, Crassostrea virginica. Natl. Cancer Inst. Monogr. 31: 557-562

Couch, J. A. (1970). Sarcoma-like disease in a single specimen of the American oyster. [Abstr.] In: Dutcher, R. M. (ed.) Comparative leukemia research 1969. S. Karger, New York, p. 647

Couch, J. A. (1984). Atrophy of diverticular epithelium as an indicator of environmental irritants in the oyster, Crassostrea virgínica. Mar. environ. Res. 14:525-526

Coluch, J. A., Winstead, J. T. (1979). Concurrent neoplastic and protistan disorders in the American oyster, Crassostrea virginica. Haliotis 8: 249-253

Couch, J. A., Courtney, L. A., Winstead, J. T., Foss, S. S. (1979). The American oyster, Crassostrea virginica, as an indicator of carcinogens in the aquatic environment. In: Nielsen, S. W. (ed.) Animals as monitors of environmental pollutants. Nat. Acad. of Sci., Washington, D.C., p. 65-83

Couch, J. A., Nimmo, D. (1974). Detection of interactions between natural pathogens and pollutants in aquatic ani- mals. In: Proc. Gulf Coast Regional Symp. Diseases of Aquatic Animals, Louisiana State University Center for Wetland Resources, LSU-5G-74-05, p. 261-265

Couch, J. A., Gardner, G., Harshbarger, J. C., Tripp, M. R. Yevich, P. P. (1974). Histological and physiological evaluations in some marine fauna. In: Marine bioassays workshop proc. 1974. Mar. Technol. Soc., Washington, D.C., p. $156-173$

Couch, J. A., Harshbarger, J. C. (1985). Effects of carcinogenic agents on aquatic animals: an environmental and experimental overview. J. Environ. Sci. Heaith, Part C, Environ. Carcinog. Rev. 3: 63-105

Dawe, C. (1969). Phylogeny and oncogeny. Natl. Cancer Inst. Monogr. 31: 1-39

Dawe, C. J., Harshbarger, J. C. (ed.) (1969). Neoplasms and related disorders of invertebrate and lower vertebrate animals. Natl. Cancer Inst. Monogr. 31: 772

Farley, C. A. (1969). Probable neoplastic disease of the hematopoietic system in oysters, Crassostrea virginica and Crassostrea gigas. Natl. Cancer Inst. Monogr. 31: 772

Farley, C. A., Sparks, A. K. (1970). Proliferative diseases of hemocytes, endothelial cells, and connective tissue cells in mollusks. Bibl. Haematol. 36: 610-617

Frierman, E. M. (1976). Occurrence of hematopoietic neoplasms in Virginia oysters (Crassostrea virginica). Mar. Fish. Rev. 38(10): 34-36

Hard, G. C., Williams, R., Lee, J. (1979). Histopathology of superficial fish 'tumors' found during a cancer survey of demersal species in Port Philip Bay, Victoria, Australia. J. Fish Dis. 2: 455-467

Harshbarger, J. C., Chang, S. C., Otto, S. V. (1977). Chlamydiae (with phages), mycoplasmas, and Rickettsiae in Chesapeake Bay bivalves. Science 196(4290): 666-668

Hoffman, G. L. (1967). Parasites of North American freshwater fishes. University of California Press, Berkeley

Howse, H. D., Christmas, J. Y. (1970). Lymphocystis tumors: histochemical identification of hyaline substances. Trans. Am. microsc. Soc. 89(2): 276-282

Howse, H. D., Christmas, J. Y. (1971). Observations on the ultrastructure of lymphocystis virus in the Atlantic croaker, Micropogon undulatus (Linnaeus). Virology 44(1): $211-214$

Kimura, I., Taniguchi, N., Kumai, H., Tomita, I., Kinae, N., Yoshizaki, K., Ito, M., Ishikawa, T (1984). Correlation of epidemiological observations with experimental data: chemical induction of chromatophoromas in the croaker Nibea mitsukurii. In: Proceedings of a symposium on the use of small fish species in carcinogenicity testing. Natl. Cancer Inst. Monogr. 65: 139-154

Laseter, J. L., Lawler, G. C. (1982). GC-MS analysis of potential carcinogenic organic pollutants in aquatic organisms and sediments. Report R80467-02 of a cooperative agreement to the U.S.E.P.A. from the Center for Bio-Organic Studies. University of New Orleans, New Orleans, Louisiana

Lauckner, G. (1983). Diseases of Mollusca: Bivalvia. In: Kinne, O. (ed.) Diseases of marine animals, Vol. 2. Biologische Anstalt Helgoland, Hamburg, p. 477-961

Lowe, J. I., Parrish, P. R., Patrick, J. M. Jr., Forester, J. (1972). Effects of the polychlorinated biphenyl Aroclor 1254 on the American oyster, Crassostrea virginica. Mar. Biol. 17: 209-214

Mackin, J. G. (1951). Histopathology of infections of Crassostrea virginica (Gmelin) by Dermocystidium marinum Mackin, Owen and Collier. Bull. mar. Sci. Gulf Carib. 1: $72-87$

Mackin, J. G., Owen, H. M., Collier, A. (1950). Preliminary 
note on the occurrence of a new protistan parasite, Dermocystidium marinum n. sp., in Crassostrea virginica (Gmelin). Science III: 328-329

McCain, B. B., Grounlund, W. D., Myers, M. S., Wellings, S. R. (1979). Tumors and microbial diseases of marine fishes in Alaskan Waters. J. Fish Dis. 2: 111-130

Mearns, A. J., Sherwood, M. J. (1974). Environmental aspects of fin erosion and tumors in southern California Dover sole. Trans. Am. Fish. Soc. 103(4): 799-810

Mearns, A. J., Sherwood, M. J. (1977). Distribution of neoplasms and other diseases in marine fishes relative to the discharge of waste water. Ann. N.Y. Acad. Sci. 298: 210-224

Mix, M. C. (1975). The neoplastic disease of bivalve molluscs. In: Hampton, J. C. (ed.) The cell cycle in malignancy and immunity. NTTS No. CONF-731005. National Technical Information Service, Springfield, Virginia, p. 369-386

Mix, M. C. (1979). Chemical carcinogens in bivalve mollusks from Oregon estuaries. U.S. Environmental Protection Agoncy, EPA-600/3-79-034 Cincinnati, Ohio.

Moore, M. N., Lowe, D. M., Fieth, P. E. M. (1978). Lysosomal responses to experimentally injected Anthracene in the digestive cells of Mytilus edulis. Mar. Biol. 48: 297-302

Moore, M. N., Clarke, R. (1982). Use of microstereology and quantitative cytochemistry to determine the effects of crude oil-derived aromatic hydrocarbons on lysosomal structure and function in a marine bivalve mollusc, Mytilus edulis. Histochem. J. 14: 713-718

Overstreet, R. M., Howse, H. D. (1977). Some parasites and diseases of estuarine fishes in polluted habitats of Mississippi. Ann. N.Y. Acad. Sci. 298: 427-462

Perkins, F. O. (1976). Zoospores of the oyster pathogen, Dermocystidium marinum. II. Fine structure of the conoid and other sporozoan-like organelles. J. Parasit. 62(6): 959-974

Perkins, E. J., Gilchrist, J. R. S., Abbott, O. J. (1972). Incidence of epidermal lesions in fish of the North-East Irish Sea area, 1971. Nature, Lond. 238: 101-103

Quick, J. A. Jr., Mackin, J. G. (1971). Oyster parasitism by Labyrinthomyxa marina in Florida. Florida Dept. of Natural Resources, Marine Research Lab. Prof. Papers Series No. 13: 1-55
Rasmussen, L. (1982). Light microscopical studies of the acute toxic effects of $\mathrm{N}$-nitrosodimethylamine on the marine mussel, Mytilus edulis. J. Invertebr. Pathol. 14: 266-267

Ray, S. M. (1954). Experimental studies on the transmission and pathogenicity of Dermocystidium marinum, a fungus parasite of oysters. J. Parasit. 40: 235

Ribelin, W. E., Migaki, G. (ed.) (1975). The pathology of fishes. Univ. Wisconsin Press, Madison

Scarpelli, D. G., Rosenfield, A. (ed.) (1976). Molluscan pathology. Mar. Fish. Rev. 38(10): 1-56

Sindermann, C. J. (1954). Diseases of fishes of the western North Atlantic I. Dept. Sea and Shore Fish., Maine, Res. Bull. 18

Sindermann, C. J. (1954). Diseases of fishes of the western North Atlantic II. Dept. Sea and Shore Fish., Maine, Res. Bull. 19

Sindermann, C. J. (1979). Pollution-associated diseases and abnormalities of fish and shellfish: a review. Fish. Bull. U.S. 76(4)

Snieszko, S. F. (ed.) (1970). A symposium on diseases of fishes and shellfishes. Am. Fish. Soc. Spec. Publ. 5, p. 1-526

Sprague, V. (1965). Ichthyosporidium Caullery and Mesnil, 1905. The name of a genus of fungi or a gemus of sporozoans. Syst. Zool. 14: 110-114

Sprague, V. (1977). Systematics of the Microsporidia. In: Bulla, L. A. Jr., Cheng, T. C. (ed.) Comparative pathobiology. Vol 2

Stich, H. F., Acton, A. B., Oishi, K., Yamazaki, F., Harada, T., Hibino, T., Moser, H. G. (1977). Systematic collaborative studies on neoplasms in marine animals as related to the environment. Ann. N.Y. Acad. Sci. 298: 374-388

Tubiash, H. D., Hendricks, J. D. (1973). A possible lipoma in the weakfish, Cynoscion regalis (Bloch and Schneider). Chesapeake Sci. 14: 145-146

Weissenberg, R. (1965). Fifty years of research on the lymphocystis virus disease of fishes (1914-1964). Ann. N.Y. Acad. Sci. 126: 363-374

Winstead, J. T., Couch, J. A. (1981). Proctoeces sp. (Trematoda: Digenea) in the American oyster, Crassostrea virginica. Trans. Am. microsc. Soc. 100(3): 296-305 